\title{
The Interaction of $\alpha_{2}$-Macroglobulin with Proteinases
}

\author{
CHARACTERISTICS AND SPECIFICITY OF THE REACTION, AND \\ A HYPOTHESIS CONCERNING ITS MOLECULAR MECHANISM
}

\author{
By ALAN J. BARRETT and PHYLLIS M. STARKEY \\ Tissue Physiology Department, Strangeways Research Laboratory, Cambridge CB1 4RN, U.K.
}

\author{
(Received 29 January 1973)
}

\begin{abstract}
1. $\alpha_{2}$-Macroglobulin is known to bind and inhibit a number of serine proteinases. We show that it binds thiol and carboxyl proteinases, and there is now reason to believe that $\alpha_{2}$-macroglobulin can bind essentially all proteinases. 2 . Radiochemically labelled trypsin, chymotrypsin, cathepsin B1 and papain are bound by $\alpha_{2}$-macroglobulin in an approximately equimolar ratio. Equimolar binding was confirmed for trypsin by activesite titration. 3. Pretreatment of $\alpha_{2}$-macroglobulin with a saturating amount of one proteinase prevented the subsequent binding of another. We conclude that each molecule of $\alpha_{2}$-macroglobulin is able to react with one molecule of proteinase only. 4. $\alpha_{2}$-Macroglobulin did not react with exopeptidases, non-proteolytic hydrolases or inactive forms of endopeptidases. 5. The literature on binding and inhibition of proteinases by $\alpha_{2}$-macroglobulin is reviewed, and from consideration of this and our own work several general characteristics of the interaction can be discerned. 6. A model is proposed for the molecular mechanism of the interaction of $\alpha_{2}$-macroglobulin with proteinases. It is suggested that the enzyme cleaves a peptide bond in a sensitive region of the macroglobulin, and that this results in a conformational change in the $\alpha_{2}$-macroglobulin molecule that traps the enzyme irreversibly. Access of substrates to the active site of the enzyme becomes sterically hindered, causing inhibition that is most pronounced with large substrate molecules. 7. The possible physiological importance of the unique binding characteristics of $\alpha_{2}$-macroglobulin is discussed.
\end{abstract}

Human $\alpha_{2}$-macroglobulin $\left(\alpha_{2} M\right)^{*}$ is a plasma glycoprotein of molecular weight about 800000 (see reviews of Steinbuch, 1971; Heimburger et al., 1971; Bourrillon \& Razafimahaleo, 1972).

On the basis of the published work of others (see the Discussion section) and also our own experiments (Starkey, 1973; Starkey \& Barrett, 1973), it can be seen that $\alpha_{2} \mathrm{M}$ has the property of binding many proteinases (mostly 'serine' proteinases), but not other enzymes or even enzymically inactive forms of the proteinases. Once bound, the enzyme molecules are typically accessible to substrates and inhibitors of low molecular weight, but not to those of high molecular weight.

In the present paper experiments are described that were designed to test the hypothesis that $\alpha_{2} M$ has, in fact, the property of binding almost all, if not all, endopeptidases, and to give more detailed information about the nature of the process. From the results it becomes clear that $\alpha_{2} M$ undergoes a unique and specific form of interaction with proteinases, and it is possible to propose a molecular mechanism for

*Abbreviations: $\alpha_{2} \mathrm{M}, \alpha_{2}$-macroglobulin; IgM, immunoglobulin M; IgG, immunoglobulin G; Fab, antigenbinding fragment of IgG. the binding and inhibition of these enzymes. Such binding probably contributes to the physiological regulation of extracellular proteolytic activity.

\section{Materials}

Cathepsins D and B1 were prepared from human liver by the methods of Barrett $(1970,1973)$. Papain $(2 \times$ crystallized $)$, ficin $(2 \times$ crystallized $)$, bromelain (grade II), trypsin (bovine, $2 \times$ crystallized), carboxypeptidase A (bovine), hyaluronidase (ovine testis, freeze-dried: type II), soya-bean trypsin inhibitor (type II-S), Tos-LysCH $\mathrm{CH}_{2} \mathrm{Cl}$ (TLCK, 7-amino-1chloro-3-tosylamidoheptan-2-one), Z-Gly-Phe (benzyloxycarbonyl-glycyl-L-phenylalanine), Leu$\mathrm{NHC}_{6} \mathrm{H}_{4} \mathrm{NO}_{2}$ (leucine $p$-nitroanilide) and 6,9-diamino-2-ethoxyacridine lactate (Rivanol) were obtained from Sigma Chemical Co. Ltd., Kingstonupon-Thames, Surrey KT2 7BH, U.K. $\alpha$-Chymotrypsin was chymotrypsin A4 obtained from the Boehringer (London) Corp. Ltd., London W5 2TZ, U.K. $\beta$-Glucuronidase, a gift from Mr. R. T. Dean, was partially purified from rabbit liver (Dean, 1973). Trypsin (bovine, $2 \times$ crystallized) used for activesite titration was obtained from Miles-Seravac (Pty)

Vol. 133 
Ltd., Maidenhead, Berks, U.K. Aminopeptidase M was a gift from Carl Roth OHG, 75 Karlsruhe, West Germany. Cathepsin D trace-labelled with ${ }^{125}$ I, by use of lactoperoxidase and carrier-free $\mathrm{Na}^{125} \mathrm{I}$ (Marchalonis, 1969), was a gift from Dr. Z. Werb. One atom of ${ }^{125} \mathrm{I}$ was incorporated/20 molecules of cathepsin D. Carboxypeptidase A was also labelled with ${ }^{125}$ I, essentially as described by Marchalonis (1969).

Pepstatin [a pentapeptide inhibitor of cathepsin D; Barrett \& Dingle (1972)] was a gift from the Banyu Pharmaceutical Co. Ltd., 7, 2-chome, Nihonbashi Honcho, Chuo-ku, Tokyo, Japan. Sephadex G-75 (superfine grade) and G-200, and Sepharose 6B were obtained from Pharmacia (Great Britain) Ltd., London W5 5SS, U.K.

Bz-Arg- $\mathrm{NHC}_{10} \mathrm{H}_{7} \quad(\alpha-N$-benzoyl-DL-arginine 2naphthylamide) and $\mathrm{Z}$-Arg- $\mathrm{NHC}_{10} \mathrm{H}_{6} \mathrm{OMe}$ (benzyloxycarbonyl-L-arginine 4-methoxy-2-naphthylamide) were obtained from Bachem Ltd., Liestal, Switzerland. 4-Nitrophenyl 4'-guanidinobenzoate, prepared by Cyclo Chemical, Los Angeles, U.S.A., was a gift from Dr. A. Fersht. 4-Nitrophenol (spectrophotometric grade) was obtained from BDH Chemicals Ltd., Poole, Dorset BH12 4NN, U.K.

IgG preparations from rabbit antisera directed against whole human serum, human serum $\alpha_{2} M$ and human serum $\alpha_{1}$-antitrypsin (products of Dakopatts, Copenhagen, Denmark) were obtained from Mercia Diagnostics Ltd., Watford, Herts., U.K.; their specificities were confirmed by immunoelectrophoresis.

Partigen immunodiffusion plates for the determination of human $\alpha_{2} M$, and stabilized standard human serum, were obtained from Hoechst Pharmaceuticals Ltd., Brentford, Middlesex, U.K.

Pooled human serum from 100 normal donors and human plasma, group $\mathrm{O}$, were generously supplied by Dr. C. Entwhistle, Immunohaematology Unit, Addenbrooke's Hospital, Cambridge, U.K. Azocasein was prepared by treating casein with diazotized sulphanilic acid by the method of Charney \& Tomarelli (1947). The $E_{366}^{1 \%}$ of the azo-casein was 43.6.

\section{Methods}

\section{Enzyme assays}

The activity of papain against $\mathrm{Bz}-\mathrm{Arg}-\mathrm{NHC}_{10} \mathrm{H}_{7}$ (naphthylamidase activity) was assayed as described by Barrett (1972a) for cathepsin B1. Trypsin was assayed by the same method, except in that $133 \mathrm{~mm}$ Tris-HCl, pH7.5, containing $13.3 \mathrm{~mm}-\mathrm{CaCl}_{2}$ was used as the assay buffer, giving a final concentration in the incubation mixture of $100 \mathrm{~mm}$-Tris $-\mathrm{HCl}$ and $10 \mathrm{~mm}-\mathrm{CaCl}_{2}$, and the coupling reagent was $0.25 \mathrm{mg}$ of Fast Garnet $\mathrm{GBC} / \mathrm{ml}$ of $0.5 \mathrm{M}$-sodium acetate buffer (pH4.3) containing 2\% (w/v) BRIJ 35.
Aminopeptidase $\mathbf{M}$ was assayed as described by Wachsmuth et al. (1966) and carboxypeptidase A was assayed essentially as described by Neurath (1955) with Z-Gly-Phe as substrate.

Hyaluronidase, ribonuclease, $\beta$-glucuronidase and $\beta$-acetylglucosaminidase activities were assayed essentially as described by Barrett (1972b). The proteolytic activity of the commercial hyaluronidase was measured against azo-casein in incubation mixtures $(1.0 \mathrm{ml})$ containing enzyme sample $(0.5 \mathrm{ml}), 0.5 \mathrm{M}$ sodium potassium phosphate buffer, $\mathrm{pH} 7.5(0.25 \mathrm{ml})$, and $4 \%(\mathrm{w} / \mathrm{v})$ azo-casein $(0.25 \mathrm{ml})$. After $60 \mathrm{~min}$ at $40^{\circ} \mathrm{C}$, the reaction was stopped by addition of $5 \mathrm{ml}$ of $3.0 \%(w / v)$ trichloroacetic acid, and the mixtures were filtered. The $E_{366}$ of the trichloroacetic acidsoluble reaction products was determined. Blanks were prepared by addition of the enzyme sample only after the reaction had been stopped with trichloroacetic acid.

\section{Immunoelectrophoresis and gel-diffusion analysis}

Immunoelectrophoresis plates $(8 \mathrm{~cm} \times 8 \mathrm{~cm})$ were coated with $1 \%$ (w/v) Meath agarose (from Medical and Biological Instrumentation Ltd., Ashford, Kent, U.K.) in buffer containing $21.6 \mathrm{~mm}$-barbitone sodium, $21.6 \mathrm{~mm}$-sodium acetate and $0.01 \%$ thimerosal, adjusted to $\mathrm{pH} 8.2$ with $0.1 \mathrm{M}-\mathrm{HCl}$. The capacity of the antigen well was $5 \mu \mathrm{l}$, and that of the antiserum trough $50 \mu \mathrm{l}$. Electrophoresis was for $1.5 \mathrm{~h}$ at a current of $25 \mathrm{~mA} /$ plate.

For gel-diffusion analysis by the method of Ouchterlony (1967), plates were coated with $1 \%$ agarose in sodium-potassium phosphate buffer (20 mM, pH 7.0) including $0.15 \mathrm{M}-\mathrm{NaCl}$. The developed plates were photographed with dark-ground illumination by use of Agfa Scientia 39 C 56 film.

The plates were stained for activity against Z-Arg$\mathrm{NHC}_{10} \mathrm{H}_{6} \mathrm{OMe}$ by the method of Starkey \& Barrett (1973).

To stain for protein, the plate was washed for $48 \mathrm{~h}$ in phosphate-buffered saline, pH7.2 $(0.80 \% \mathrm{NaCl}$, $0.02 \% \mathrm{KCl}, 0.02 \% \mathrm{KH}_{2} \mathrm{PO}_{4}$ and $0.12 \% \mathrm{Na}_{2} \mathrm{HPO}_{4}$ ), containing $1 \%(\mathrm{v} / \mathrm{v})$ butan-1-ol, washed for $4 \mathrm{~h}$ in water, and then dried. The dried plate was immersed in $0.1 \%(\mathrm{w} / \mathrm{v})$ Coomassie Brilliant Blue in sodium formate-formic acid-ethanol-water $(4: 7: 126: 66$, $\mathrm{w} / \mathrm{v} / \mathrm{v} / \mathrm{v}$ ) for $10 \mathrm{~min}$. The background stain was rinsed out with the buffered solvent, and the plate was rinsed with water and dried.

\section{Preparation of partially purified $\alpha_{2} M$}

Method I. Normal human serum $(25 \mathrm{ml})$ was applied to a column $\left(2.5 \mathrm{~cm} \times 40 \mathrm{~cm} ; 196 \mathrm{~cm}^{3}\right)$ of Sephadex G-200 equilibrated with buffer containıng $50 \mathrm{~mm}$-sodium-potassium phosphate, $\mathrm{pH} 6.0,100 \mathrm{~mm}-$ $\mathrm{NaCl}, 1 \mathrm{~mm}$-disodium EDTA and $1 \%(\mathrm{v} / \mathrm{v})$ butan-1-ol 
(buffer A). The sample was eluted with the same buffer at a flow rate of $18 \mathrm{ml} / \mathrm{h}$ at $4^{\circ} \mathrm{C}$. Fractions $(2.5 \mathrm{ml})$ were collected, and samples run in immunoelectrophoresis and immunodiffusion against anti(whole human serum) IgG and anti-(human $\alpha_{2}$ M) IgG. The $\alpha_{2} M$ was eluted at the void volume of the column, and those fractions containing appreciable amounts of $\alpha_{2} M$ were combined $(44 \mathrm{ml})$ and stored at $4^{\circ} \mathrm{C}$.

This partially purified $\alpha_{2} \mathrm{M}$ was shown by immunoelectrophoresis against anti-(whole human serum) IgG, anti-(human $\alpha_{2}$ M) IgG and anti-(human $\alpha_{1-}$ antitrypsin) IgG to be contaminated with $\alpha$ and $\beta$ serum proteins and traces of albumin whereas $\alpha_{1}$ serum proteins, which include the proteinase inhibitors $\alpha_{1}$-antitrypsin, $\alpha_{1}$-antichymotrypsin and antithrombin III, were barely detectable. The concentration of $\alpha_{2} \mathrm{M}$ in the pool, measured by radial immunodiffusion on a Partigen plate as described by the manufacturers, was $1.38 \mathrm{mg} / \mathrm{ml}$.

Method II. Normal human plasma $(50 \mathrm{ml})$ was di-

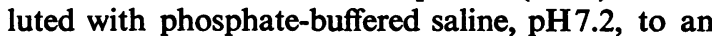
$E_{280}$ of $\mathbf{4 0}$ and adjusted if necessary to pH 7.2. Fibrinogen was precipitated by mixing 9 vol. of diluted plasma with 1 vol. of aq. $4 \%$ (w/v) Rivanol (Heimburger et al., 1971). The precipitate was removed by centrifugation and the protein in the supernatant was freed from Rivanol on a column $(4 \mathrm{~cm} \times 32 \mathrm{~cm}$; $400 \mathrm{~cm}^{3}$ ) of Sephadex G-25 equilibrated with buffer A. The column was run at a flow rate of $100 \mathrm{ml} / \mathrm{h}$ at room temperature, and the effluent (30-60\% bed vol.) containing the protein peak was pooled and concentrated by ultrafiltration in a Diaflo 50 apparatus fitted with an XM-100 membrane (Amicon Ltd., High Wycombe, Bucks., U.K.).

The concentrated plasma protein $(20 \mathrm{ml})$ was applied to a column $\left(2.5 \mathrm{~cm} \times 87.5 \mathrm{~cm} ; 430 \mathrm{~cm}^{3}\right)$ of Sepharose 6B equilibrated with buffer A. The column was eluted with the same buffer at a flow rate of $25 \mathrm{ml} /$ $h$ at $4^{\circ} \mathrm{C}$. Fractions $(5.0 \mathrm{ml})$ were collected and run in immunoelectrophoresis and immunodiffusion against anti-(whole human serum) IgG and anti-(human $\alpha_{2}$ M) IgG. Those fractions containing appreciable amounts of $\alpha_{2} \mathrm{M}$ not grossly contaminated with other proteins were pooled and concentrated by ultrafiltration as described above.

For use in the active-site titration of trypsin bound to $\alpha_{2} \mathrm{M}$, the pool of $\alpha_{2} \mathrm{M}$ was dialysed against $0.1 \mathrm{M}$ sodium barbitone- $\mathrm{HCl}$ buffer, $\mathrm{pH}$ 8.3. The concentration of $\alpha_{2} \mathrm{M}$ in the pool, measured by radial immunodiffusion as described above, was $6.0 \mathrm{mg} / \mathrm{ml}$. The major contaminants of the $\alpha_{2} M$ were haptoglobin and IgM.

\section{Preparation of radioactively labelled proteinases}

Trypsin, chymotrypsin, cathepsin B1 and papain were labelled by trace acetylation with $\left[{ }^{3} \mathrm{H}\right]$ acetic anhydride (type A1 P2A from The Radiochemical Centre, Amersham, Bucks., U.K.). Cathepsin B1 $(4.5 \mathrm{mg})$ was dissolved in $2 \mathrm{ml}$ of buffer $(0.80 \% \mathrm{NaCl}$, $\left.0.02 \% \mathrm{KCl}, 0.60 \% \mathrm{KH}_{2} \mathrm{PO}_{4}, 0.086 \% \mathrm{Na}_{2} \mathrm{HPO}_{4}\right)$, pH6.0, containing $50 \mathrm{~mm}$-sodium acetate, and each of the other three proteins $(25 \mathrm{mg})$ was dissolved in $1 \mathrm{ml}$ of phosphate-buffered saline, $\mathrm{pH} 7.2$, containing $50 \mathrm{~mm}$-sodium acetate. The protein solutions were cooled to $0^{\circ} \mathrm{C}$ and $\left[{ }^{3} \mathrm{H}\right]$ acetic anhydride $(500 \mu \mathrm{Ci}$ in $5 \mu l$ of benzene) was introduced into each, with vigorous mixing. The reaction mixtures were left for $1 \mathrm{~h}$ at $0^{\circ} \mathrm{C}$ before free $\left[{ }^{3} \mathrm{H}\right]$ acetate was removed by dialysis against several changes of phosphate-buffered saline containing $50 \mathrm{~mm}$-sodium acetate. The efficiency of incorporation of tritium into protein was about $20 \%$.

The specific radioactivity of the labelled proteins was calculated from the $E_{278}$ or $E_{280}$ and radioactivity of the trichloroacetic acid-insoluble material, the $E_{280}^{1 \%}$ values being taken as 15.6 and 20.2 for trypsin and $\alpha$-chymotrypsin respectively (Sobers, 1970), 20.0 for cathepsin B1 (Barrett, 1973) and $E_{278}^{1 \%}$ as $\mathbf{2 5 . 0}$ for papain (Sobers, 1970). The molar substitution values in $\mathrm{mol}$ of $\left[{ }^{3} \mathrm{H}\right]$ acetyl $/ \mathrm{mol}$ of enzyme were: trypsin, $1.24 ; \alpha$-chymotrypsin, 0.28 ; cathepsin B1, 0.74: papain, 0.71 .

In calculation of the molar ratios for binding of enzymes to $\alpha_{2} M$, molecular weights were taken as follows; trypsin, 23300 and $\alpha$-chymotrypsin, 25000 (calculated from amino acid compositions given by Dayhoff \& Eck, 1968), cathepsin B1, 25500 (Barrett, 1973), papain, 23400 (Mitchel et al., 1970) and $\alpha_{2} \mathrm{M}$, 820000 (Dunn \& Spiro, 1967; Frénoy et al., 1972). The molecular weight of soya-bean trypsin inhibitor was taken as 21700 (Birk \& Gertler, 1971).

\section{Scintillation counting}

Aqueous samples (up to $0.1 \mathrm{ml}$ ) were counted in a Packard Tri-Carb liquid-scintillation spectrometer model 3375 in $10 \mathrm{ml}$ of scintillant solution (Hall \& Cocking, 1965). The efficiency of counting was $25 \%$ $\left({ }^{3} \mathrm{H}\right)$ or $49 \%\left({ }^{125} \mathrm{I}\right)$.

\section{Results}

Binding by $\alpha_{2} M$

Binding of thiol and carboxyl proteinases. Hartley (1960) proposed the classification of proteinases on the basis of the chemical nature of the groups involved in catalysis. Four classes were recognized: serine proteinases, thiol proteinases, acid proteinases (perhaps better called carboxyl proteinases, now that the nature of the catalytic groups has been elucidated) and metal proteinases. Evidence for the binding of proteinases by $\alpha_{2} \mathrm{M}$ was confined to the serine proteinases until the binding of cathepsin B1, a thiol 
proteinase, was demonstrated (Starkey \& Barrett, 1973). It has now been possible to show the binding of three other thiol proteinases, and of cathepsin D, a carboxyl proteinase.

Binding of plant thiol proteinases. In an attempt to establish the capacity of $\alpha_{2} M$ to bind thiol proteinases in general, we examined the binding of papain, ficin and bromelain by serum or plasma.

Human serum $(5 \mathrm{ml})$ was mixed with $5 \mathrm{ml}$ of buffer A containing $2 \mathrm{mM}$-cysteine and $200 \mu \mathrm{g}$ of papain, the molar ratio papain $/ \alpha_{2} \mathrm{M}$ being $0.5: 1.0$. The mixture was incubated at $4^{\circ} \mathrm{C}$ for $1 \mathrm{~h}$ and then applied to a column $\left(2.5 \mathrm{~cm} \times 87.5 \mathrm{~cm} ; 430 \mathrm{~cm}^{3}\right)$ of Sephadex G-75 equilibrated with buffer $A$. The sample was eluted with the same buffer at a flow rate of $19 \mathrm{ml} / \mathrm{h}$ at $4^{\circ} \mathrm{C}$, and $4 \mathrm{ml}$ fractions were collected and assayed for naphthylamidase activity. The distribution of $\alpha_{2} \mathrm{M}$ in the fractions was determined immunologically.

One peak of naphthylamidase activity was eluted at the exclusion volume of the column, the distribution of activity closely following that of $\alpha_{2} \mathrm{M}$. There was no naphthylamidase activity eluted at the volume characteristic of free papain.

The fraction containing the maximum naphthylamidase activity was run in double immunodiffusion against rabbit anti-(whole human serum) IgG and rabbit anti-(human $\alpha_{2} \mathrm{M}$ ) IgG. The gel-diffusion plate was washed for $48 \mathrm{~h}$ at $4^{\circ} \mathrm{C}$ in phosphate-buffered saline (see the Methods sections) and stained for activity against $\mathrm{Z}$-Arg- $\mathrm{NHC}_{10} \mathrm{H}_{6} \mathrm{OMe}$ (Starkey \& Barrett, 1973). The coloured reaction product appeared over precipitin lines formed against the anti$\left(\alpha_{2} M\right)$ IgG; against the anti-(whole human serum) IgG there was a weak reaction only over a line showing identity with the specific anti- $\left(\alpha_{2} M\right)$ line.

It was concluded that $\alpha_{2} M$ has the capacity to bind papain; there was no evidence of binding by other serum proteins under the conditions used.

Bromelain (4mg) was activated by incubation for $10 \mathrm{~min}$ at room temperature in $0.5 \mathrm{ml}$ of buffer $A$ containing $4 \mathrm{~mm}$-cysteine and $2 \mathrm{~mm}$-disodium EDTA. The activated enzyme $(400 \mu \mathrm{g}$ in $0.05 \mathrm{ml})$ was mixed with $0.9 \mathrm{ml}$ of human plasma and $0.1 \mathrm{ml}$ of concentrated (10-fold) buffer $\mathrm{A}$, and incubated at $4^{\circ} \mathrm{C}$ for $30 \mathrm{~min}$. Ficin $(400 \mu \mathrm{g})$ was activated and incubated with plasma in the same way.

Samples of the enzyme-plasma mixtures were run in immunoelectrophoresis against anti-(whole human serum) IgG and anti-(human $\alpha_{2}$ M) IgG. The plate was then washed and stained for activity against $\mathrm{Z}$-Arg- $\mathrm{NHC}_{10} \mathrm{H}_{6} \mathrm{OMe}$ as described above. With both bromelain (Plate 1) and ficin the coloured reaction product appeared only over those precipitin lines due to $\alpha_{2} M$. It was concluded that $\alpha_{2} M$, but no other serum protein, bound ficin and bromelain. The bound enzyme was at least partially active.

Binding of cathepsin $D$. Human serum $(5 \mathrm{ml})$ was mixed with $4.6 \mathrm{ml}$ of buffer A. Cathepsin D (127 units, $250 \mu \mathrm{g}$, in $0.2 \mathrm{ml}$ ) and ${ }^{125} \mathrm{I}$-labelled cathepsin D $\left(7 \mu \mathrm{g}, 3.27 \times 10^{6}\right.$ d.p.m., in $\left.0.2 \mathrm{ml}\right)$ were then added and the mixture was left at $20^{\circ} \mathrm{C}$ for $18 \mathrm{~h}$. The sample was applied to a column $\left(2.5 \mathrm{~cm} \times 87.5 \mathrm{~cm} ; 430 \mathrm{~cm}^{3}\right)$ of Sephadex G-75 equilibrated with buffer A. The sample was eluted with the same buffer at a flow rate of $14 \mathrm{ml} / \mathrm{h}$ at $4^{\circ} \mathrm{C}$, and $4 \mathrm{ml}$ fractions were collected and assayed for radioactivity. The distribution of $\alpha_{2} M$ in the fractions was determined immunologically.

As a control, cathepsin $\mathbf{D}$ was run on a column as described above except in that the human serum was replaced by crystalline bovine serum albumin $(50 \mathrm{mg}$ in $5 \mathrm{ml}$ ). About $3 \%$ of the total radioactivity was eluted at the void volume, probably indicating the presence of aggregated protein in the enzyme sample, and it was therefore necessary to correct for this in the column runs of cathepsin $\mathbf{D}$ with serum.

From the corrected results (Fig. 1) it was calculated that $21 \%$ of the total ${ }^{125}$ I-labelled cathepsin D was eluted at the exclusion volume of the column, the distribution of radioactivity closely following that of $\alpha_{2} M$. The remaining $79 \%$ of the radioactivity was eluted at the volume characteristic of free cathepsin $D$, and may well have represented enzyme inactivated



Fig. 1. Gel chromatography of ${ }^{125}$ I-labelled cathepsin $D$ after incubation with human serum in the presence or absence of pepstatin

Distribution of radioactivity and $\alpha_{2} M$ in effluent from a Sephadex G-75 column on which ${ }^{125}$ I-labelled cathepsin $D$ had been run after incubation with human serum alone (-) or with $1 \mu \mathrm{g}$ of pepstatin/ $\mathrm{ml}(----)$. The results have been corrected by subtraction of counts attributable to high-molecularweight material in the enzyme preparation itself (see the text for details). The horizontal bar indicates the distribution of $\alpha_{2} \mathrm{M}$ in fractions from both runs. 


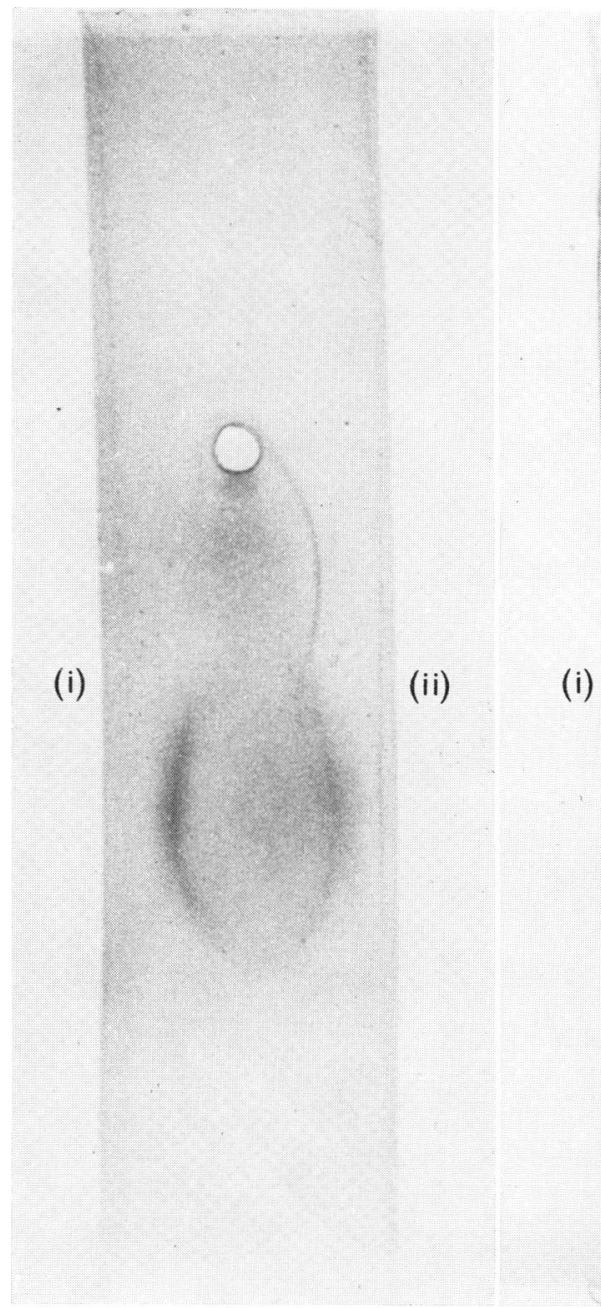

(a)

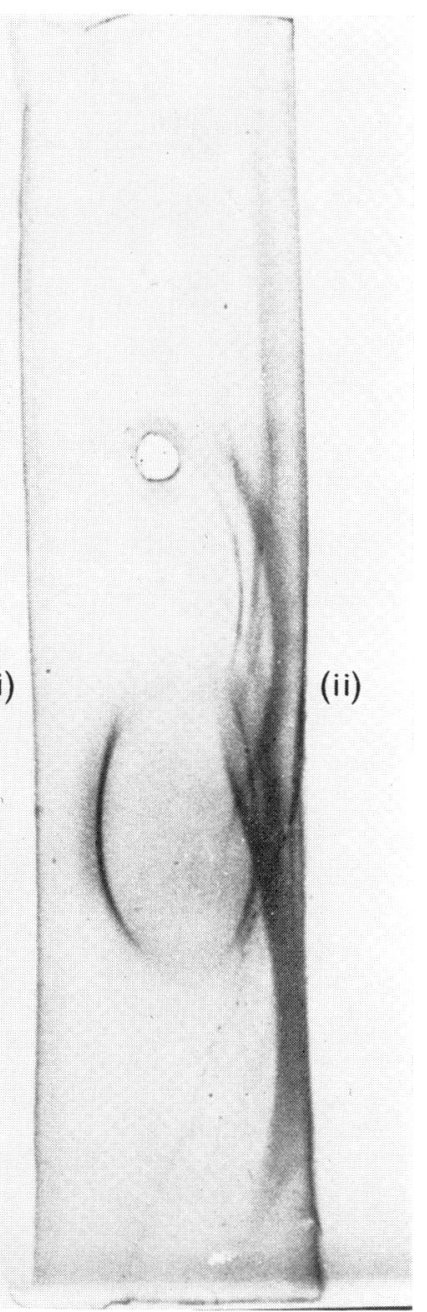

(b)

EXPLANATION OF PLATE I

Binding of bromelain by $\alpha_{2} M$ demonstrated by immunoelectrophoresis

A mixture of activated bromelain and normal human plasma was run in immunoelectrophoresis and the plate was developed with (i) anti-(human $\alpha_{2}$ M) IgG and (ii) anti-(whole human serum) IgG. The plate was stained $(a)$ for enzymic activity of bromelain and $(b)$ for protein (see the text for details). In $(a)$ only precipitin lines formed by $\alpha_{2} \mathrm{M}$ developed the red colour indicating the naphthylamidase activity of bromelain. The sharp line visible close to the well was due to non-specific yellow staining of a precipitin line by the diazonium salt. 
during iodination, or the rather prolonged storage to which the preparation had been subjected.

The importance of enzymic activity for binding was tested by use of pepstatin, a potent reversible inhibitor of cathepsin D (Barrett \& Dingle, 1972). In the presence of pepstatin $(1 \mu \mathrm{g} / \mathrm{ml})$ the amount of ${ }^{125}$ I-labelled cathepsin $\mathrm{D}$ bound to the $\alpha_{2} \mathrm{M}$ was decreased from $21 \%$ of the total enzyme to $8 \%$ (Fig. 1). When the amount of pepstatin was increased to $25 \mu \mathrm{g} / \mathrm{ml}$, the binding of cathepsin D was diminished still further, but not completely prevented.

\section{Number of proteinase molecules bound per molecule of $\alpha_{2} M$}

Stoicheiometry of binding of radioactively labelled trypsin, chymotrypsin, cathepsin $B 1$ and papain. The stoicheiometry of binding of several proteinases by $\alpha_{2} \mathrm{M}$ was determined by incubation of the ${ }^{3} \mathrm{H}$-labelled enzymes with the partially purified protein, and separation of the enzyme-inhibitor complexes from free enzyme by gel chromatography. At least two experiments were made with each enzyme, in approximately 10-fold and 40-fold molar excess over $\alpha_{2} M$.

Partially purified $\alpha_{2} \mathrm{M}$, prepared by method 1 $(2.07 \mathrm{mg}$ in $1.5 \mathrm{ml})$, was mixed with ${ }^{3} \mathrm{H}$-labelled enzyme (approx. $0.5 \mathrm{mg}$ or $2 \mathrm{mg}$ in $0.5 \mathrm{ml}$, except with trypsin, where the amounts were increased to approx. $2 \mathrm{mg}$ or $8 \mathrm{mg}$ to compensate for the loss of enzymic activity during storage) and the appropriate buffer $(0.5 \mathrm{ml})$. For trypsin and chymotrypsin, the buffer contained $0.50 \mathrm{M}-\mathrm{Tris}-\mathrm{HCl}, \mathrm{pH} 8.0$, and $1 \%(\mathrm{v} / \mathrm{v})$ butan-1-ol, whereas for cathepsin B1 and papain the buffercontained $0.25 \mathrm{M}$-sodium-potassium phosphate, pH6.0, 0.50 $\mathrm{M}-\mathrm{NaCl}, 5 \mathrm{~mm}$-disodium EDTA, $10 \mathrm{~mm}$ cysteine and $1 \%(\mathrm{v} / \mathrm{v})$ butan-1-ol. Each complete mixture was incubated at $4^{\circ} \mathrm{C}$ for $1 \mathrm{~h}$. A portion of $0.1 \mathrm{ml}$ was taken for scintillation counting, and the remainder of the mixture $(2.4 \mathrm{ml})$ was applied to a column $\left(1.5 \mathrm{~cm} \times 25.5 \mathrm{~cm} ; 45 \mathrm{~cm}^{3}\right)$ of Sepharose $6 \mathrm{~B}$ equilibrated with buffer $\mathbf{A}$. The sample was eluted with buffer $A$ at a flow rate of $10 \mathrm{ml} / \mathrm{h}$ at $4^{\circ} \mathrm{C}$. Fractions $(1 \mathrm{ml})$ were collected and assayed for radioactivity. The distribution of $\alpha_{2} \mathrm{M}$ was determined by immunodiffusion.

The amount of enzyme bound to $\alpha_{2} \mathbf{M}$ was calculated from the total radioactivity contained in those fractions in which $\alpha_{2} M$ could be detected immunologically (see Fig. 2). For each enzyme the amount of radioactivity bound to $\alpha_{2} M$ at the two enzyme activities was the same within experimental error, showing that the $\alpha_{2} \mathrm{M}$ had been completely saturated, and strongly indicating that the enzymes were bound in definite molar ratios. Because there is strong reason for thinking that binding by $\alpha_{2} \mathrm{M}$ is irreversible (see below), the number of molecules of an enzyme bound per molecule of $\alpha_{2} \mathrm{M}$ would be expected to be an integer. For each enzyme tested the nearest integer was one (results summarized in Table 1). The ratios were calculated on the simplifying assumption that the specific radioactivity of the total labelled enzyme preparation was that of the active enzyme that was bound. The failure to obtain ratios closer to unity for papain, cathepsin B1 and chymotrypsin may have been due to slight differences between the two specific activities.

Active-site titration of trypsin bound to $\alpha_{2} M$. Several attempts have been made by other workers to determine the absolute molarity of trypsin bound to $\alpha_{2} \mathrm{M}$ by means of rate assays (see the Discussion section), but these introduce the difficulty of ascertaining the molecular activity of the bound trypsin. Often investigators have assumed that crystalline trypsin obtained commercially was completely pure and fully active, and taken the molecular activity of this as their standard, an assumption that certainly is not justified. We have adopted the alternative approach of making an active-site titration, or 'burst assay', of bound trypsin by the method of Chase \& Shaw (1967). This procedure gives the absolute molarity of

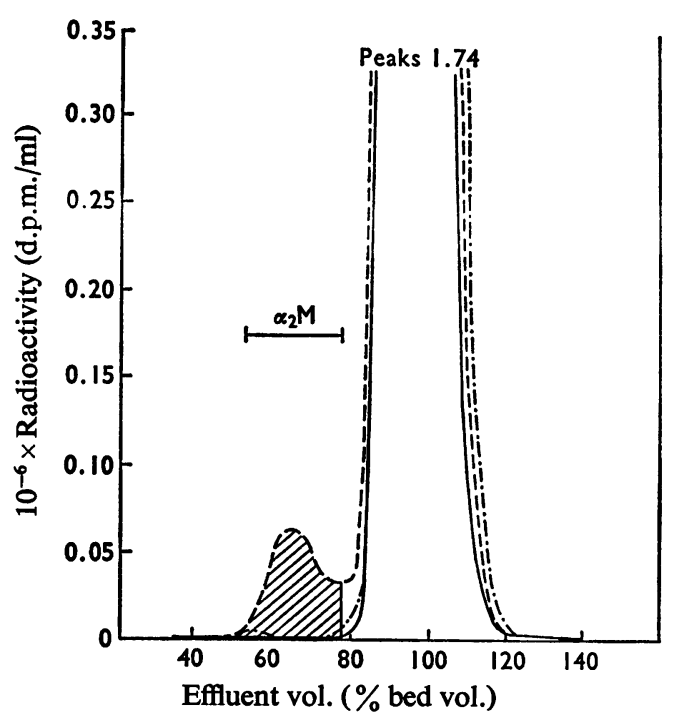

Fig. 2. Gel chromatography of ${ }^{3} \mathrm{H}$-labelled chymotrypsin after incubation with partially purified $\alpha_{2} M$ or $\alpha_{2} M$ pretreated with papain

Distribution of radioactivity and $\alpha_{2} M$ in effluent from a Sepharose 6B column. Samples were ${ }^{3} \mathrm{H}$ labelled chymotrypsin alone (-), the enzyme incubated with $\alpha_{2} M(---)$ and the enzyme incubated with $\alpha_{2} M$ that had been pretreated with papain $(-\cdot-\cdot)$. The hatched area represents the amount of chymotrypsin bound to $\alpha_{2} M$ (see the text for details). The horizontal bar indicates the range of distribution of $\alpha_{2} M$ in fractions from all three runs. 
Table 1. Binding of ${ }^{3} \mathrm{H}$-labelled enzymes to $\alpha_{2} M$

The tritium-labelled enzymes were incubated with $2.07 \mathrm{mg}$ of $\alpha_{2} \mathrm{M}$ and run in gel chromatography. The amount of enzyme bound was calculated as is shown for chymotrypsin in Fig. 3.

\begin{tabular}{|c|c|c|c|c|}
\hline $\begin{array}{c}{ }^{3} \mathrm{H} \text {-labelled } \\
\text { enzyme }\end{array}$ & $\begin{array}{c}10^{-6} \times \text { Specific } \\
\text { radioactivity } \\
\text { of enzyme } \\
\text { (d.p.m. } / \mathrm{mg})\end{array}$ & $\begin{array}{l}\text { Amount } \\
\text { of } \\
\text { enzyme } \\
(\mathrm{mg})\end{array}$ & $\begin{array}{c}10^{-6} \times \text { Radioactivity } \\
\text { bound to } \alpha_{2} \mathrm{M} \\
\text { (d.p.m.) }\end{array}$ & $\begin{array}{c}\text { Amount of } \\
\text { enzyme bound } \\
\left(\mathrm{mol} / \mathrm{mol} \text { of } \alpha_{2} \mathrm{M}\right)\end{array}$ \\
\hline Trypsin & 29.5 & $\begin{array}{l}1.7^{*} \\
1.7 \dagger \\
8.6\end{array}$ & $\begin{array}{l}1.67 \\
1.56 \\
1.73\end{array}$ & $\begin{array}{l}1.01 \\
0.94 \\
1.05\end{array}$ \\
\hline Chymotrypsin & 6.22 & $\begin{array}{l}0.64 \\
2.40\end{array}$ & $\begin{array}{l}0.50 \\
0.48\end{array}$ & $\begin{array}{l}1.35 \\
1.28\end{array}$ \\
\hline Cathepsin B1 & 16.0 & $\begin{array}{l}0.58 \\
2.32\end{array}$ & $\begin{array}{l}0.53 \\
0.50\end{array}$ & $\begin{array}{l}0.54 \\
0.51\end{array}$ \\
\hline Papain & 16.9 & $\begin{array}{l}0.54 \\
2.20\end{array}$ & $\begin{array}{l}0.71 \\
0.80\end{array}$ & $\begin{array}{l}0.75 \\
0.84\end{array}$ \\
\hline
\end{tabular}

* Enzyme run with freshly prepared $\alpha_{2} M$.

$\dagger$ Enzyme run with $\alpha_{2} \mathrm{M}$ that had been stored at $4^{\circ} \mathrm{C}$ for 3 weeks.

active sites able to react with the low-molecularweight substrate, 4-nitrophenyl 4'-guanidinobenzoate, and the rate of reaction does not affect the final result. The difficulty of preparing the $\alpha_{2} M$-trypsin complex free from an excess of either reactant was circumvented by taking advantage of the ability of $\alpha_{2} \mathbf{M}$ to protect trypsin from inhibition by soya-bean trypsin inhibitor (Ganrot, 1966).

Up to $3 \mathrm{mg}(3.7 \mathrm{nmol})$ of partially purified $\alpha_{2} \mathrm{M}$ (prepared by method II) in $0.85 \mathrm{ml}$ of $0.10 \mathrm{M}$-sodium barbitone- $\mathrm{HCl}$ buffer, pH8.3, containing $20 \mathrm{~mm}-$ $\mathrm{CaCl}_{2}$, was mixed with $0.50 \mathrm{mg}$ of trypsin (shown to be $11.8 \mathrm{nmol}$, by titration) freshly dissolved in $0.05 \mathrm{ml}$ of $0.05 \mathrm{M}$-sodium formate buffer, $\mathrm{pH} 3.0$, containing $1 \mathrm{~mm}-\mathrm{CaCl}_{2}$. The mixture, in a semi-micro-spectrophotometer cuvette, was incubated for $10 \mathrm{~min}$ at $25^{\circ} \mathrm{C}$, and $1.4 \mathrm{mg}$ of soya-bean trypsin inhibitor was introduced in $0.10 \mathrm{ml}$ of the barbitone buffer. After $2 \mathrm{~min}$, during which the $E_{410}$ of the solution was measured, $37.3 \mu \mathrm{g}$ (100 nmol) of 4-nitrophenyl 4'guanidinobenzoate (in $10 \mu \mathrm{l}$ of dimethyl sulphoxide) was mixed in, and the $E_{410}$ was remeasured $15 \mathrm{~s}$ later and again at $30,45,60,90,120,150$ and $180 \mathrm{~s}$. The $E_{410}$ values were plotted as a function of time and extrapolated back to give the value at zero time, which was taken as the 'burst'. The initial rapid increase in $E_{410}$ was complete at $15 \mathrm{~s}$; thereafter there occurred a slow release that was linear with time. This slow release was observed with trypsin in the presence or absence of soya-bean trypsin inhibitor, and was probably due to the non-enzymic hydrolysis also observed by Chase \& Shaw (1967).

Controls were prepared by replacing $\alpha_{2} \mathbf{M}$, trypsin or soya-bean trypsin inhibitor solutions (or all three) by the appropriate buffer.
The molar extinction coefficient of 4-nitrophenol in the barbitone buffer was 16750 litre $\cdot \mathrm{mol}^{-1} \cdot \mathrm{cm}^{-1}$ in our spectrophotometer (Cecil Instruments Ltd., Cambridge CB4 1TG, U.K., model 272). This value may becompared with $16595 \mathrm{litre} \cdot \mathrm{mol}^{-1} \cdot \mathrm{cm}^{-1}$ reported by Chase \& Shaw (1967). The 'burst' of 4-nitrophenol obtained with trypsin alone, at various enzyme concentrations, was directly proportional to the trypsin concentration, and was completely unaffected by the presence of $\alpha_{2} \mathrm{M}$ up to $3 \mathrm{mg} / \mathrm{ml}$. No 'burst' was obtained with trypsin in the presence of soya-bean trypsin inhibitor. The purity of the commercial trypsin preparation was $61 \%$ (on the basis of a molecular weight of 23300). 4-Nitrophenyl 4'guanidinobenzoate showed a significant rate of spontaneous hydrolysis in the buffer alone. No 'burst' was obtained with $\alpha_{2} \mathrm{M}$ alone, but at the higher concentrations it slightly increased the slow, non-enzymic hydrolysis.

The result of an experiment in which the protection of trypsin by $\alpha_{2} M$ was measured is given in Fig. 3. The slope of the curve corresponds to a molar ratio of bound trypsin to $\alpha_{2} M$ of 1.04. In addition, the finding that the titre of trypsin was unaffected by the presence of $\alpha_{2} \mathrm{M}$ indicates that partial inhibition by $\alpha_{2} \mathrm{M}$ results from a decrease in the rate of reaction, rather than inactivation of a proportion of the catalytic sites.

Effect of pretreatment of $\alpha_{2} M$ with a proteinase on subsequent binding of a second proteinase. In view of the widely differing substrate specificities and physical properties of proteinases bound by $\alpha_{2} \mathrm{M}$ it was of interest to decide whether molecules of different enzymes occupy the same site on $\alpha_{2} M$.

Papain $(1 \mathrm{mg}$ in $0.04 \mathrm{ml}$ ) was activated with $2 \mathrm{mM}$ cysteine $(0.36 \mathrm{ml})$ and then added to $\alpha_{2} \mathrm{M}(2.76 \mathrm{mg}$ 


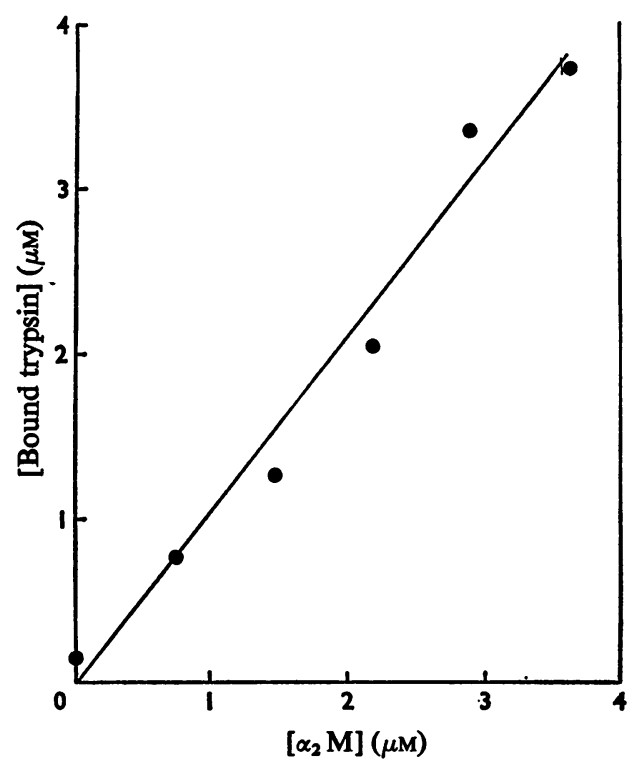

Fig. 3. Active-site titration of trypsin bound to $\alpha_{2} M$

Trypsin $(0.50 \mathrm{mg}, 11.8 \mathrm{nmol})$ was allowed to react with partially purified $\alpha_{2} \mathrm{M}$ (up to $3.0 \mathrm{mg}, 3.7 \mathrm{nmol}$ ) before an excess of soya-bean trypsin inhibitor $(1.4 \mathrm{mg}, 64.7 \mathrm{nmol})$ was introduced into the $1 \mathrm{ml} \mathrm{re}-$ action volume. The molarity of trypsin protected from inhibition by binding to $\alpha_{2} M$ was calculated from the 'burst' of 4-nitrophenol released after the addition of 4-nitrophenyl-4'-guanidinobenzoate $(33.7 \mu \mathrm{g}, 100 \mathrm{nmol})$ (see the text for details). The linear regression line was calculated by an unweighted least-squares analysis.

in $2.0 \mathrm{ml}$ ) and the complete mixture, in which papain was in approximately 10 -fold molar excess over $\alpha_{2} \mathrm{M}$, was incubated at $4^{\circ} \mathrm{C}$ for $1 \mathrm{~h}$. A sample $(1.8 \mathrm{ml})$ of the solution was mixed with ${ }^{3} \mathrm{H}$-labelled chymotrypsin $(2.4 \mathrm{mg}$ in $0.20 \mathrm{ml}$; approximately 40 -fold molar excess over $\alpha_{2} \mathrm{M}$ ) and $0.5 \mathrm{ml}$ of buffer containing $0.50 \mathrm{M}-\mathrm{Tris}-\mathrm{HCl}, \mathrm{pH} 8.0$, and $1 \%(\mathrm{v} / \mathrm{v})$ butan-1-ol, and after incubation at $4^{\circ} \mathrm{C}$ for $1 \mathrm{~h}$ the whole mixture was applied to a column of Sepharose $\mathbf{6 B}$ and eluted under the conditions described above.

As is shown in Fig. 2, preincubation of the $\alpha_{2} \mathrm{M}$ with a saturating amount of papain almost completely prevented the subsequent binding of chymotrypsin by the $\alpha_{2} M$. The possibility that exposure to papain had resulted in a degradation of the $\alpha_{2} M$ was eliminated, because $\alpha_{2} M$ appeared at its normal effluent volume, and gave an immunological reaction of the expected type and intensity with its specific antiserum.

In a second experiment the binding of trypsin to $\alpha_{2} M$ that had been treated with cathepsin B1 was measured. $\alpha_{2} \mathrm{M}(2.76 \mathrm{mg}$ in $2.0 \mathrm{ml})$ was mixed with human cathepsin $B 1(2.15 \mathrm{mg}$ in $0.4 \mathrm{ml})$ and $120 \mathrm{~mm}$ cysteine $(0.04 \mathrm{ml})$ at $\mathrm{pH} 6.0$, and the complete mixture was incubated at $4^{\circ} \mathrm{C}$ for $1 \mathrm{~h}$. A sample $(1.8 \mathrm{ml})$ of the solution was then incubated at $4^{\circ} \mathrm{C}$ for $1 \mathrm{~h}$ with ${ }^{3} \mathrm{H}$ labelled trypsin $(1.7 \mathrm{mg}$ in $0.2 \mathrm{ml})$ and buffer containing $0.50 \mathrm{M}$-Tris $-\mathrm{HCl}, \mathrm{pH} 8.0$, and $1 \%(\mathrm{v} / \mathrm{v})$ butan- $1-\mathrm{ol}$ $(0.5 \mathrm{ml})$. The molar excess of cathepsin B1 over $\alpha_{2} M$ was 10 -fold, and that of trypsin 40 -fold. The complete mixture was applied to a column of Sepharose 6B and eluted under the conditions described above. Pretreatment of the $\alpha_{2} M$ with cathepsin $\mathrm{B} 1$ decreased the subsequent binding of ${ }^{3} \mathrm{H}$ labelled trypsin to $16 \%$ of the control value obtained with untreated $\alpha_{2} \mathbf{M}$.

It was concluded that $\alpha_{2} \mathrm{M}$ can be saturated with one proteinase, so that the binding of another is very greatly decreased, and that this indicates that the different endopeptidases are bound at a common site.

\section{Specificity of the binding capacity of $\alpha_{2} M$ for active} proteinases

Requirement of enzymic activity for binding of trypsin. Experiments were made to elucidate the nature of the requirement of activity for the binding of enzymes to $\alpha_{2} M$. Binding was considered in terms of two distinct stages: the initial interaction of the two molecules, and the subsequent maintenance of binding.

${ }^{3} \mathrm{H}$-labelled trypsin $(4.2 \mathrm{mg}$ in $0.25 \mathrm{ml})$ was totally inactivated by incubation with Tos- $\mathrm{LySCH}_{2} \mathrm{Cl}$, an irreversible active-site-directed inhibitor of the enzyme (Shaw et al., 1965) (1 mg), in 0.5 $\mathrm{M}$-Tris-HCl buffer, pH8.0 $(0.6 \mathrm{ml})$, and water $(0.35 \mathrm{ml})$ at $4^{\circ} \mathrm{C}$ for approx. $18 \mathrm{~h}$.

The inactivated enzyme was mixed with partially purified $\alpha_{2} \mathrm{M}$ prepared by method I $(2.5 \mathrm{mg}$ in $1.8 \mathrm{ml})$ and incubated at $4^{\circ} \mathrm{C}$ for $1 \mathrm{~h}$. A sample of the mixture $(2.5 \mathrm{ml})$ was applied to a column $(1.5 \mathrm{~cm} \times 26 \mathrm{~cm}$, $46 \mathrm{~cm}^{3}$ ) of Sepharose $6 \mathrm{~B}$ equilibrated with buffer $A$. The sample was eluted with the same buffer at $4^{\circ} \mathrm{C}$ and a flow rate of $10 \mathrm{ml} / \mathrm{h} ; 1 \mathrm{ml}$ fractions were collected and their radioactivity was determined.

Only one peak of radioactivity was eluted from the column (Fig. 4), at the elution volume characteristic of free trypsin; there was no peak of radioactivity associated with the $\alpha_{2} M$. Thus the inactivation of trypsin with Tos- $\mathrm{Lys} \mathrm{CH}_{2} \mathrm{Cl}$ had prevented its binding by $\alpha_{2} \mathrm{M}$.

In a second experiment, partially purified $\alpha_{2} M$ (5 $\mathrm{mg}$ in $3.6 \mathrm{ml}$ ) was mixed with buffer containing $0.5 \mathrm{M}$-Tris- $\mathrm{HCl}, \mathrm{pH} 8.0(1.2 \mathrm{ml})$, water $(0.7 \mathrm{ml})$ and ${ }^{3} \mathrm{H}$-labelled trypsin $(8.3 \mathrm{mg}$ in $0.5 \mathrm{ml})$, and incubated at $4^{\circ} \mathrm{C}$ for $1 \mathrm{~h}$. The mixture was divided into two portions. One portion $(2.5 \mathrm{ml})$ was applied to a column of Sepharose 6B and run as described above.

Vol. 133 


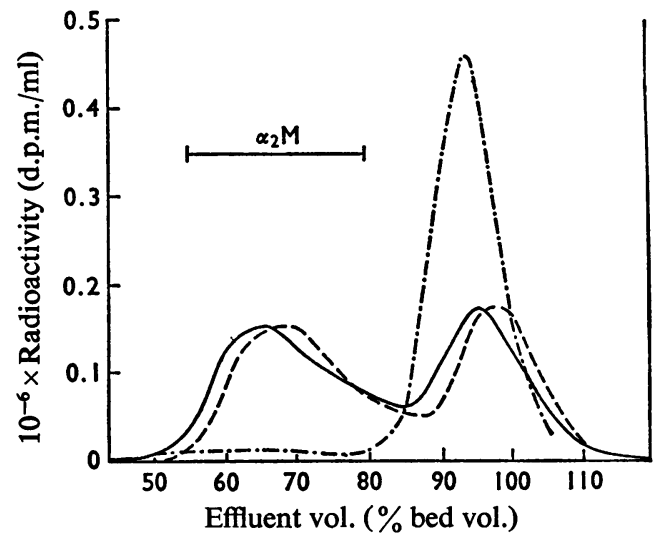

Fig. 4. Gel chromatography of ${ }^{3} \mathrm{H}$-labelled trypsin exposed to Tos- $\mathrm{LysCH}_{2} \mathrm{Cl}$ before or after incubation with partially purified $\alpha_{2} M$

Distribution of radioactivity in effluent from a Sepharose 6B column. Samples were ${ }^{3} \mathrm{H}$-labelled trypsin incubated with $\alpha_{2} \mathrm{M}(-)$, the same sample treated with Tos- $\mathrm{LySCH}_{2} \mathrm{Cl}$ (----) and the enzyme treated with Tos- $\mathrm{LysCH}_{2} \mathrm{Cl}$ before incubation with $\alpha_{2} M(-\cdot-\cdot-)$ (see the text for details). The horizontal bar indicates the distribution of $\alpha_{2} M$ in fractions from a separate run on the same column under identical conditions.

The second portion $(3.0 \mathrm{ml})$ was mixed with $1 \mathrm{mg}$ of Tos- $\mathrm{LysCH}_{2} \mathrm{Cl}$ and incubated at $4{ }^{\circ} \mathrm{C}$ for about $18 \mathrm{~h}$. The mixture was shown to have lost all naphthylamidase activity. A sample $(2.5 \mathrm{ml})$ was applied to a column of Sepharose 6B and eluted under the conditions described above.

The distribution of radioactivity in the fractions from the two column runs was similar (Fig. 4). In each run, two peaks of radioactivity were obtained, the first being eluted with the $\alpha_{2} M$ and the second at the volume characteristic of free trypsin.

Thus inhibition by Tos- $\mathrm{LysCH}_{2} \mathrm{Cl}$ of trypsin already bound to $\alpha_{2} \mathrm{M}$ did not cause the dissociation of trypsin from the $\alpha_{2} M$. In other words, enzymic activity was not required for the maintenance of binding to $\alpha_{2} \mathrm{M}$. The finding that the order of mixing of trypsin, Tos- $\mathrm{LysCH}_{2} \mathrm{Cl}$ and $\alpha_{2} \mathrm{M}$ affected the final result of their interaction is characteristic of an irreversible or pseudo-irreversible interaction, rather than a reversible one.

Failure of $\alpha_{2} M$ to react with exopeptidases. Two exopeptidases were incubated with a molar excess of $\alpha_{2} M$, and the resulting mixtures were subjected to gel chromatography.

Aminopeptidase $M(0.5 \mathrm{mg})$ was incubated with $5 \mathrm{mg}$ of $\alpha_{2} \mathrm{M}$ partially purified from plasma by method II, in $1.5 \mathrm{ml}$ of buffer $(75 \mathrm{~mm}-\mathrm{Tris}-50 \mathrm{~mm}$ $\mathrm{HCl}, \mathrm{pH} 7.8$ ) at room temperature for $30 \mathrm{~min}$. The mixture was then run on a column $(0.9 \mathrm{~cm} \times 50 \mathrm{~cm}$, $31.5 \mathrm{~cm}^{3}$ ) of Sepharose $6 \mathrm{~B}$ in the same Tris- $\mathrm{HCl}$ buffer at a flow rate of $8 \mathrm{ml} / \mathrm{h}$ at $4^{\circ} \mathrm{C}$. The distribution of $\alpha_{2} \mathrm{M}$ in the effluent fractions was determined by immunodiffusion, and that of aminopeptidase $\mathbf{M}$ by assays for enzymic activity. The enzymic activity appeared as a single peak at a greater effluent volume than that of $\alpha_{2} \mathrm{M}$. It was concluded that aminopeptidase $M$ was not bound by $\alpha_{2} M$.

A similar experiment was made with ${ }^{125} \mathrm{I}$-labelled carboxypeptidase A $(50 \mu \mathrm{g})$ and $\alpha_{2} \mathrm{M}(5 \mathrm{mg})$, except in that the Sepharose column was run in $0.05 \mathrm{M}$ sodium barbitone- $\mathrm{HCl}$ buffer, $\mathrm{pH} 8.3$. About $20 \%$ of the enzymic activity that was eluted from the column, and a similar proportion of the proteinbound radioactivity, was eluted with the $\alpha_{2} \mathbf{M}$, whereas the remainder appeared in a retarded peak.

Further experiments were made to establish whether the characteristics of binding of carboxypeptidase $\mathrm{A}$ to $\alpha_{2} \mathrm{M}$ are similar to those of endopeptidases. When 1,10-phenanthroline, an inactivator of carboxypeptidase, was added to the reaction mixture (at a final concentration of $1 \mathrm{~mm}$ ) either before or after the enzyme, it was found that no radioactive enzyme was bound by $\alpha_{2} M$. The finding that the order of mixing of $\alpha_{2} \mathbf{M}$, carboxypeptidase and inhibitor did not affect the final result, in contrast with the situation with trypsin and Tos- $\mathrm{Lys} \mathrm{CH}_{2} \mathrm{Cl}$, shows that the binding of carboxypeptidase is reversible. The binding of the enzyme also did not appear to be specific for $\alpha_{2} M$, since it was completely reversed by introducing $30 \mathrm{mg}$ of crystalline bovine serum albumin into the mixture. Active carboxypeptidase was bound by $\alpha_{2} M$ that had been pretreated with a molar excess of trypsin, and $\alpha_{2} M$ that had been treated with carboxypeptidase retained its ability to bind bromelain, as was shown by immunoelectrophoresis.

It was concluded from these results that the characteristics of binding of carboxypeptidase A to $\alpha_{2} \mathbf{M}$ are different in important respects from those of the endopeptidases. The binding is readily reversible, not specific for $\alpha_{2} M$ and does not take place at the same site on the $\alpha_{2} \mathrm{M}$ molecule as is occupied by endopeptidases.

Failure of $\alpha_{2} M$ to bind several non-proteolytic hydrolases. Commercial ovine testicular hyaluronidase $(10 \mathrm{mg})$ in $2 \mathrm{ml}$ of buffer containing $5 \mathrm{~mm}$-sodiumpotassium phosphate, $\mathrm{pH} 7.0$, was incubated with $4 \mathrm{ml}$ of human serum at $4^{\circ} \mathrm{C}$ for $1 \mathrm{~h}$. The mixture was applied to a column $\left(2.5 \mathrm{~cm} \times 40.5 \mathrm{~cm}, 198 \mathrm{~cm}^{3}\right)$ of Sepharose 6B equilibrated with buffer $A$. The sample was eluted with the same buffer at a flow rate of $30 \mathrm{ml} / \mathrm{h}$ at $4^{\circ} \mathrm{C}$. Fractions $(2.0 \mathrm{ml})$ were collected and assayed for hyaluronidase, $\beta$-acetylglucosaminidase, ribonuclease and proteolytic activity against azocasein. (Commercial testicular hyaluronidase is rich 
in activity of many hydrolytic enzymes.) Also, the distribution of $\alpha_{2} M$ was determined. In another experiment the hyaluronidase was replaced by partially purified rabbit liver $\beta$-glucuronidase (1 i.u. in $2.0 \mathrm{ml})$.

The non-proteolytic enzymes hyaluronidase, $\beta$ acetylglucosaminidase, ribonuclease and $\beta$-glucuronidase were each eluted at an effluent volume much greater than that of $\alpha_{2} \mathrm{M}$; there was no indication of binding. In contrast, the enzyme active against azocasein showed a bimodal distribution, the position of the first peak being correlated with the distribution of $\alpha_{2} \mathrm{M}$. In a control experiment the commercial hyaluronidase was run without serum, and a single peak of activity against azo-casein was obtained at a similar elution volume to that of the second peak in the first experiment. It was concluded that only the proteolytic enzyme was bound by $\alpha_{2} M$.

\section{Discussion}

It can be shown that the interaction of $\alpha_{2} M$ with proteinases has some clearly defined general characteristics, and from these a molecular mechanism for the interaction can be proposed. Some of the consequences of this unique interaction are considered.

\section{General characteristics of the interaction}

Three important aspects of the interaction of proteinases with $\alpha_{2} M$ are illustrated by the collation of information in Table 2.

First, many proteinases interact with $\alpha_{2} \mathrm{M}$, and as they represent all four classes of these enzymes (Hartley, 1960) they differ widely in catalytic mechanism and specificity. Several of the serine proteinases are bound and inhibited by $\alpha_{2} M$, but the binding of the thiol proteinases, cathepsin B1, papain, ficin and bromelain was definitely established only recently, although Thomas and co-workers (Thomas, 1964) showed binding of papain to an $\alpha$-globulin of rabbit plasma. In the present paper we have also shown the binding of cathepsin $\mathrm{D}$, a carboxyl proteinase. The binding of proteinases of the fourth class, the metal proteinases, has been demonstrated with thermolysin, clostridiopeptidase $\mathrm{A}$ and mammalian collagenases (Z. Werb, M. C. Burleigh, A. J. Barrett \& P. M. Starkey, unpublished work).

None of the other inhibitors of proteinases from plasma and many other sources (see Steinbuch, 1971; Fritz \& Tschesche, 1971) shares the apparent capacity of $\alpha_{2} \mathrm{M}$ to react with this whole functional group of enzymes. Since there is also evidence that $\alpha_{2} M$ is specific for the proteinases (see below), it seems to be unique among the natural and synthetic inhibitors of these enzymes. Inactivated forms of the proteinases, as well as zymogens such as plasminogen and prothrombin, are not bound by $\alpha_{2} \mathrm{M}$.

The second point made by Table 2 is that the inhibition of a proteinase by $\alpha_{2} M$ has often been shown to be accompanied by binding to the macroglobulin. As is explained below, we postulate that binding is, in fact, the most important aspect of the interaction with $\alpha_{2} \mathrm{M}$, that it is irreversible, and that the inhibition is a secondary result of binding.

The third point is that, in the presence of $\alpha_{2} \mathrm{M}$, the reactivity of a proteinase with high-molecular-weight substrates and inhibitors typically is decreased to a much greater degree than that with low-molecularweight compounds. This point has often been commented on before for particular enzymes, but as a general phenomenon it is relevant to the molecular mechanism of the interaction of $\alpha_{2} \mathrm{M}$ with proteinases discussed below.

The binding of one non-proteolytic enzyme, the cationic form of aspartate aminotransferase, has been reported (Boyde \& Pryme, 1968; Boyde, 1969). Boyde provides evidence that this is a reversible electrostatic phenomenon involving the carbohydrate moiety of the macroglobulin, but his suggestion that the binding of the proteolytic enzymes is also electrostatic is not consistent either with the failure of the inactivated enzymes to bind, or with the binding of cathepsin B1, the isoelectric point of which is about 5.0 (Barrett, 1973), very close to that of $\alpha_{2} \mathrm{M}$. Insulin and growth hormone, at one time thought to be bound by $\alpha_{2} M$, probably are not (Keehan et al., 1967; Berson \& Yalow, 1966; Adham et al., 1969). In the present work we have been unable to show the binding by $\alpha_{2} \mathrm{M}$ of such hydrolases as hyaluronidase, $\beta$-acetylglucosaminidase, ribonuclease and $\beta$-glucuronidase. It is clear from the large literature on the electrophoretic analysis of enzymes in serum that many other non-proteolytic enzymes also are not bound. The exopeptidase, aminopeptidase $M$, was not found to be bound, and the binding of carboxypeptidase $\mathbf{A}$ was of a quite different kind from that of the endopeptidases.

From the available information on the interaction of proteinases with $\alpha_{2} \mathrm{M}$, certain general characteristics of the binding process can be discerned. There is ample evidence to establish that proteinases interact with $\alpha_{2} M$ to form complexes in which the two components are tightly associated, in a simple stoicheiometric ratio. This evidence is discussed below in terms of three questions. Is the association between a proteinase molecule and $\alpha_{2} \mathrm{M}$ irreversible, or very tight but reversible? What is the stoicheiometric ratio of binding? Does the binding of a molecule of one proteinase prevent the subsequent binding of another proteinase?

There are strong grounds for thinking that the binding of an enzyme molecule by $\alpha_{2} \mathrm{M}$ is irreversible; this has been particularly well demonstrated by 
Table 2. Binding and

A summary of the literature and of recent results from the authors' laboratory is given. For some of the enzymes grouped as serine rabbit macroglobulin refer to the $\alpha_{1}$ protein shown by Berne et al. (1971) to be homologous with human $\alpha_{2} \mathrm{M}$. The arbitrary of substrates and inhibitors conform to the IUPAC-IUB recommendations (1971) where applicable (Biochem. J. 126, 773antitrypsin, STI is soya-bean trypsin inhibitor, LBTI is lima-bean trypsin inhibitor, EWTI is egg-white trypsin inhibitor and PPI

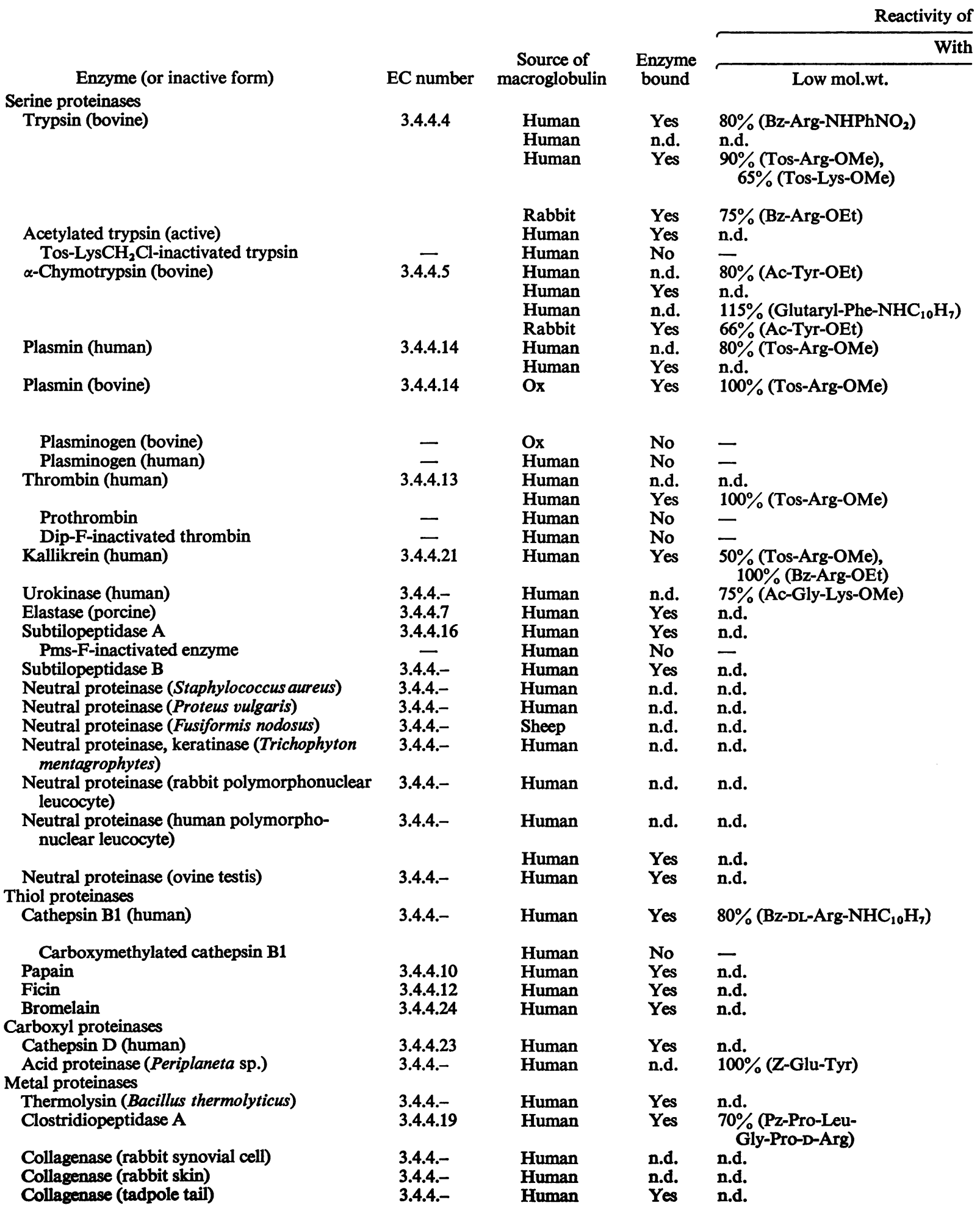


inhibition of proteinases by $\alpha_{2} M$

proteinases, and for the Periplaneta acid proteinase, there is inadequate evidence to allow definite classification. Results for the division between low and high molecular weight for substrates and inhibitors was made at 8000 daltons. Abbreviations of names 780); $-\mathrm{NHC}_{10} \mathrm{H}_{7}$ is 2-naphthylamide, $-\mathrm{NHPhNO}_{2}$ is 4-nitroanilide, Pms-F is phenylmethanesulphonyl fluoride, $\alpha_{1} \mathrm{AT}$ is $\alpha_{1}$ is polypeptide proteinase inhibitor (Trasylol). n.d., Not determined.

active site of bound enzyme as percentage of that of free enzyme

substrates

High mol.wt.

$5 \%$ (casein)

n.d.

9\% (casein), $0 \%$ (fibrinogen)

n.d.

n.d.

$25 \%$ (casein)

n.d.

n.d.

n.d.

$6 \%$ (casein)

n.d.

$0 \%$ (casein), $0 \%$ (fibrin)

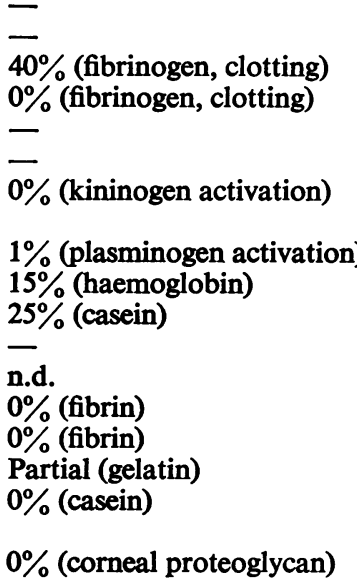

Partial (casein)

Partial (fibrinogen)

n.d.

$50 \%$ (azo-haemoglobin), $0 \%$ (collagen)

n.d.

n.d.

n.d.

n.d.

$0 \%$ (hide powder)

n.d.

$3 \%$ (collagen)

$0 \%$ (collagen)

$0 \%$ (collagen)

$0 \%$ (collagen)
With inhibitors

Low mol.wt.

High mol.wt.

Reference

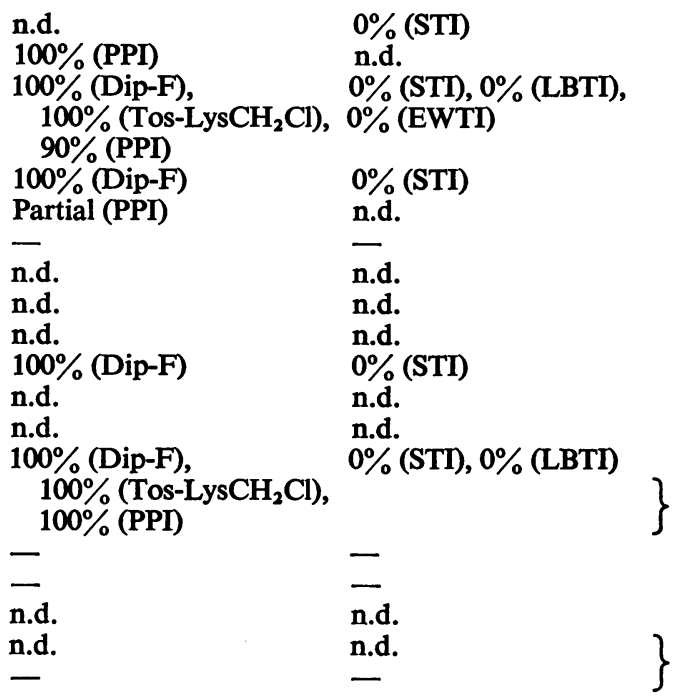

n.d.

$\overline{0 \%}$ (STI),

$0 \%$ (CI inactivator)

n.d.

n.d.

n.d.

n.d.

Partial $\left(\alpha_{1}\right.$ AT)

n.d.

n.d.

n.d.

n.d.

n.d.

n.d.

n.d.

n.d.

n.d.

n.d.

n.d.

n.d.

n.d.

n.d.

n.d.

n.d.

n.d.

n.d.

$100 \%$ (Tos-PheCH $\mathrm{CH}_{2} \mathrm{Cl}$ Partial (IgG)

$\begin{array}{lc}\text { n.d. } & \text { n.d. } \\ \text { n.d. } & \text { n.d. } \\ \text { n.d. } & \text { n.d. } \\ \text { n.d. } & \text { n.d. } \\ \text { n.d. } & \text { n.d. } \\ \text { n.d. } & \text { n.d. } \\ \text { n.d. } & \text { n.d. } \\ \text { n.d. } & \text { n.d. } \\ \text { n.d. } & \text { n.d. } \\ \text { n.d. } & \text { n.d. }\end{array}$

Ganrot (1966)

Jacquot-Armand \& Krebs (1969)

Nagasawa et al. (1970)

Berthillier et al. (1968)

Jacquot-Armand \& Krebs (1969)

Present paper

Iwamoto \& Abiko (1970)

Haverback et al. (1962)

Saunders et al. (1971)

Berthillier et al. (1968)

Iwamoto \& Abiko (1970)

Niléhn \& Ganrot (1967)

Sugihara et al. (1971)

Niléhn \& Ganrot (1967)

Iwamoto \& Abiko (1970)

Lanchantin et al. (1966)

Steinbuch (1971)

Harpel (1970)

Ogston et al. (1973)

Baumstark (1970)

Wicher \& Dolovich (1971)

Kueppers \& Bearn (1966)

Merritt et al. (1971)

Yu et al. (1972)

Brown et al. (1972)

Koj et al. (1972)

Ohlsson (1971a)

Present paper

Starkey \& Barrett (1973),

Z. Werb, M. C. Burleigh, A. J. Barrett \& P. M. Starkey (unpublished work)

Present paper

Present paper

Landureau \& Steinbuch (1970)

Werb (1973)

Z. Werb, M. C. Burleigh, A. J. Barrett \& P. M. Starkey (unpublished work)

Abe \& Nagai (1972a) 
Saunders et al. (1971), by use of ${ }^{131}$ I-labelled trypsin, and by Abe \& Nagai (1972a) for tadpole tail collagenase. Further persuasive evidence for the irreversibility of binding of proteinases by $\alpha_{2} \mathrm{M}$ comes from work reviewed below showing that $\alpha_{2} M$ can be saturated with one enzyme so as to prevent the subsequent binding of another.

Norman (1958) dealt with the inhibition of plasmin by the 'immediate inhibitor' (subsequently identified as $\alpha_{2} M$ by Schultze et al., 1963) as a reversible process, but his data are more easily interpreted by the saturation kinetics expected of irreversible binding. More recently, Niléhn \& Ganrot (1967) showed that the electrophoretic mobility of $\alpha_{2} \mathrm{M}$ was increased by interaction with plasmin, and interpreted this as an indication of reversible binding. The results are equally consistent with the irreversible formation of a complex of greater electrophoretic mobility than free $\alpha_{2} \mathbf{M}$, as was shown to be the case for trypsin (Saunders et al., 1971). The inhibition of trypsin and chymotrypsin bound by $\alpha_{2} M$ have been described as competitive or non-competitive (Nagasawa et al., 1970; Lebreton de Vonne et al., 1972), although tight, stoicheiometric binding was demonstrated at the same time, so that Michaelis-Menten kinetics may not have been applicable.

The conclusion that the binding of a proteinase molecule by $\alpha_{2} M$ is an irreversible process clearly implies that a definite number of binding sites should exist on each $\alpha_{2} \mathrm{M}$ molecule, giving a simple binding ratio. Such ratios have indeed been reported for several enzymes. In experiments with radioactively labelled proteinases we obtained molar ratios ranging from $0.5-1.3$ for the binding of cathepsin B1, papain, trypsin and chymotrypsin, and tentatively concluded that each of these enzymes was bound in an equimolar ratio by $\alpha_{2} \mathrm{M}$. This conclusion was confirmed for trypsin by active-site titration, which gave a ratio of 1.04 molecules of trypsin per molecule of $\alpha_{2} \mathrm{M}$. Thus the results contrast with the 2:1 ratio reported for trypsin by Ganrot (1966) and Saunders et al. (1971). A 2:1 ratio was also reported for chymotrypsin with rabbit $\alpha_{1}$-macroglobulin and $\alpha_{2} \mathbf{M}$ (Berthillier et al., 1968; Lebreton de Vonne et al., 1971); although Saunders et al. (1971) obtained an equimolar ratio with human $\alpha_{2}$ M. Dolovich \& Wicher (1971) reported a 2:1 ratio for the binding of subtilopeptidase $A$, whereas equimolar ratios were described for elastase (Baumstark, 1970) and for plasmin (Sugihara et al., 1971) with bovine proteins. It is important to note, however, that the calculation of each of the above 2:1 ratios, with the exception of that of Ganrot (1966), depends upon the implicit assumption that enzyme preparations obtained commercially were $100 \%$ pure and active. In fact, it is well known that commercial samples of trypsin and chymotrypsin, for example, are more usually $50-70 \%$ active (see Bender et al., 1966), and this would necessitate corrections bringing these ratios close to unity. This difficulty was noted by Mehl et al. (1964). We conclude that the available evidence points to the binding of proteinases in general in an equimolar ratio to $\alpha_{2} \mathbf{M}$.

The idea that all proteinases are bound in the same ratio is supported by the evidence that $\alpha_{2} M$ can be saturated with one enzyme, so that it is unable to bind another. For example, in our work, pretreatment of $\alpha_{2} \mathrm{M}$ with papain blocked the binding of chymotrypsin, and with cathepsin B1, that of trypsin. Previously it had been shown that pretreatment with trypsin prevented the binding of chymotrypsin and vice versa (Berthillier et al., 1968; Saunders et al., 1971). A similar relationship exists for subtilopeptidase A and trypsin (Dolovich \& Wicher, 1971). Experiments on the inhibition of enzymes by $\alpha_{2} M$ showed that presaturation with plasmin prevented the inhibition of thrombin (Ganrot \& Niléhn, 1967), and with trypsin that of polymorphonuclear leucocyte neutral proteinase (Koj et al., 1972) and mouse bone collagenase (Sakamoto et al., 1972).

\section{A hypothesis concerning the molecular mechanism of interaction of $\alpha_{2} M$ with proteinases}

On the basis of the available evidence, we would propose a working hypothesis concerning the molecular mechanism of interaction. We suggest that binding is initiated by a proteolytic attack on the $\alpha_{2} \mathrm{M}$ molecule, and that this results in a conformational change such that the enzyme molecule is irreversibly trapped within the $\alpha_{2} M$ molecule. The inhibition of enzymic activity results from the steric hindrance of access of substrates to the enzyme in its enclosed environment. We have found it useful, if somewhat fanciful, to consider the process in terms of a trap, in which the 'bait' is represented by a part of the $\alpha_{2} M$ molecule that is susceptible to attack by many proteinases; the trap is 'sprung' by cleavage of a peptide bond in this region. There results a conformational change, and the enzyme molecule is enclosed in such a way that escape of the enzyme and entry of other large molecules are prevented.

This hypothesis implies that the binding of an enzyme by $\alpha_{2} M$ must be considered as a two-stage process:

$$
\begin{gathered}
\mathrm{E}+\mathrm{M} \rightleftharpoons \mathrm{EM} \rightarrow \mathrm{EM}^{\prime} \\
\mathrm{EM}^{\prime} \rightarrow \mathrm{EM}^{*}
\end{gathered}
$$

The first stage consists of the proteolytic attack of the enzyme (E) on $\alpha_{2} M(M)$. In the second stage, the proteolytically modified macroglobulin molecule (M) undergoes a conformational change (forming $M^{*}$ ) such that the enzyme molecule becomes entrapped. The evidence concerning each stage is now considered in more detail.

. It is apparent from Table 2 that all the enzymes interacting with $\alpha_{2} \mathrm{M}$ are active endopeptidases (with 
the exceptions of cationic aspartate aminotransferase and carboxypeptidase A dealt with above). Inactive forms of the enzymes are not bound even though, apart from the catalytic site, they may be structurally identical with the active enzyme. It is difficult to escape the conclusion that endopeptidase activity is essential for the first stage of binding. We have shown that exopeptidases, and other non-proteolytic hydrolases are not bound by $\alpha_{2} M$ in the same way.

It follows from the concept that proteolytic activity is required for the initiation of binding, that a potent reversible inhibitor should delay the process. This was found for cathepsin Dinhibited by pepstatin, although the concentration of this potent inhibitor that was required was somewhat surprising. Equally, a good substrate would be expected to compete with $\alpha_{2} M$, and this offers a reasonable explanation of the data of Norman (1958) for plasmin, with casein as substrate.

As explained above, there is reason to believe that the binding site of a molecule of $\alpha_{2} \mathrm{M}$ is available to almost any proteinase, but the specificities of susceptible enzymes are so varied that the idea that the trap is 'sprung' by scission of one unique peptide bond is virtually excluded. Rather, it seems probable that a specific region of the polypeptide chain is particularly vulnerable to attack for steric reasons. This might well be a non-globular region similar to the 'hinge' region of IgG (Sarma et al., 1971; Clamp \& Johnson, 1972) and the peptide links between globular units of plasma albumin (Wilson \& Foster, 1971) that are particularly susceptible to proteolysis. Even such specific endopeptidases as mammalian collagenase (Evanson, 1971), thrombin (Magnusson, 1971) and human kallikrein (Greenbaum, 1971) are bound, although bovine kallikrein is not (Sugihara et al., 1971).

In contrast with the immediate reaction of trypsin, chymotrypsin and plasmin with $\alpha_{2} \mathrm{M}$, thrombin is bound slowly (Iwamoto \& Abiko, 1970), perhaps because $\alpha_{2} M$ is a poor substrate for this enzyme. Trypsin is bound preferentially when trypsin and chymotrypsin are presented to rabbit $\alpha_{1}$-macroglobulin simultaneously (Berthillier et al., 1968), presumably because the macroglobulin is attacked more rapidly by trypsin.

In the absence of any direct evidence for the cleavage of a peptide bond during the interaction of $\alpha_{2} M$ with proteinases, it is necessary to consider the possibility that the postulated conformational change in $\alpha_{2} M$ is triggered simply by its non-covalent interaction with the specificity site of a proteinase. The implications of the diverse specificities of the proteinase bound by $\alpha_{2} \mathrm{M}$ make this hard to accept, however. Several binding sites would seem to be required, each capable of triggering the conformational change in $\alpha_{2} \mathrm{M}$ and each losing its affinity for the enzyme in the conformational change, so that the enzyme regains activity. The comparable 'conservative' hypothesis put forward for the mechanism of action of polypeptide inhibitors (Feeney, 1971; Ako et al., 1972) is supported by evidence that catalytically inactive enzyme molecules are bound by the inhibitors. This is not true of $\alpha_{2} \mathrm{M}$, and, moreover, plasminogen, which seems to have an active binding site (Deutsch \& Mertz, 1970) but no catalytic activity, is not bound by $\alpha_{2} \mathrm{M}$ (Steinbuch et al., 1968; Sugihara et al., 1971).

We proposed in our working hypothesis that the second stage of interaction of a proteolytic enzyme molecule with $\alpha_{2} M$ consists of a conformational change whereby the enzyme molecule is entrapped. The idea of a conformational change receives support from the report of Morelis et al. (1969) of a change in the electron-microscopic appearance of rabbit $\alpha_{1}$ macroglobulin after its interaction with trypsin, a finding recently extended to human $\alpha_{2} \mathbf{M}$ by $\mathrm{E}$. A. Munn \& A. J. Barrett (unpublished results). It was also noted by Saunders et al. (1971) that human $\alpha_{2} M$ became more anodal after binding trypsin despite the fact that the free enzyme showed a cathodal mobility. A similar change was produced on inactivation of $\alpha_{2} \mathbf{M}$ with methylamine or ammonia (Heimburger et al., 1971). Evidence of another kind comes from the physiological studies of Niléhn \& Ganrot (1967) and Ohlsson $(1971 b, c)$, who found that complexes of $\alpha_{2} \mathrm{M}$ with plasmin or trypsin were cleared from the circulation with a half-time of minutes, as compared with many days for native $\alpha_{2} \mathbf{M}$.

From data such as those in Table 2, it is very clear that the reactivity of bound enzyme molecules is much greater with low-molecular-weight substrates and inhibitors than with those of high molecular weight. This effect is consistent with steric hindrance of access of large molecules to the enzyme, and is strikingly similar to the immuno-inhibition of proteolytic enzymes by antibodies, a steric phenomenon (Arnon, 1967). In trapping the enzyme, the $\alpha_{2} M$ molecule apparently also prevents access to the enzyme of large molecules from the bulk phase.

The kinetic effects of the sequestration of an enzyme molecule by one of $\alpha_{2} \mathrm{M}$ would be expected to be complex. It has been shown that both pHdependence and apparent $K_{m}$ of endopeptidases acting on low-molecular-weight substrates can be altered either by the proximity of a charged structure (in this case, parts of the $\alpha_{2} M$ molecule), or by the restriction of diffusion of substrates or products (Warton et al., 1968; Axén et al., 1970; Katchalski et al., 1971). Probably this kind of effect accounts for occasional reports of the slight activation, rather than inhibition, of enzymes after their interaction with $\alpha_{2}$ M (Gentou et al., 1968; Saunders et al., 1971).

If it is reasonable to consider the binding site of $\alpha_{2} \mathrm{M}$ in terms of a trap, available information allows us some idea of its dimensions. The enzymes known 
to be bound by $\alpha_{2} \mathrm{M}$ range in molecular weight from 23400 (papain) to 108000 (plasmin). On the basis of the relationship of size to molecular weight assumed for spherical protein molecules by Rodbard \& Chrambach (1971), this means that the trap can contain a molecule of diameter $6.4 \mathrm{~nm}$. The entrance must be small enough to prevent the escape of the globular molecule of papain, and the entry of the trypsin inhibitor not only of soya-bean (mol.wt. 21 700; Birk \& Gertler, 1971) but also of lima bean (mol.wt. about 9000; Stevens, 1971), although not that of the polypeptide proteinase inhibitor of bovine tissues (mol.wt. 6500; Ganrot, 1967). This would put the limiting dimension of the entrance of the closed trap in the range $2.5-3.0 \mathrm{~nm}$. Bound cathepsin B1 was without activity against collagen, although $50 \%$ reactivity remained with azo-haemoglobin (Starkey \& Barrett, 1973); the latter substrate contained subunits of $17000 \mathrm{~mol}$.wt. and, moreover, the molecules would have been denatured and so were probably not globular. Several enzymes retain their antigenicity when bound, e.g. subtilopeptidase A (Dolovich \& Wicher, 1971), plasmin (Niléhn \& Ganrot, 1967) and tadpole tail collagenase (Abe \& Nagai, 1972a). Presumably the reaction with antibody did not require entry of an entire IgG molecule (mol.wt. 160000 ) into the binding site, but merely penetration of part of an Fab arm (diameter 3.0-4.0nm, Sarma et al., 1971). It seems that inhibition of activity of an enzyme bound by $\alpha_{2} M$ is no greater than would necessarily follow from trapping of the enzyme.

It has been reported that elastase bound to $\alpha_{2} M$ digests the macroglobulin during prolonged incubation, and so escapes (Baumstark, 1970); because of this, the inhibition was termed 'temporary'. Tadpole tail collagenase was released in an active form from its complex by selective denaturation of the $\alpha_{2} \mathrm{M}$ with sodium thiocyanate (Abe \& Nagai, 1972a), and trypsin was released by exposure of its complex to $\mathrm{pH} 2$ (Nagasawa et al., 1970). These observations indicate that there is no covalent bond between the bound enzyme and the macroglobulin.

It has been pointed out by Sundaram et al. (1971) that it is worthwhile to distinguish 'bound' from 'entrapped' enzyme molecules, and to this extent references to the 'binding' of enzymes by $\alpha_{2} M$ above are misleading. For example, the term 'binding site' could apply either to the region susceptible to proteolysis, or to the part of the molecule that entraps the enzyme.

The concept of entrapment helps to explain two somewhat surprising aspects of the binding of enzymes by $\alpha_{2} M$ : the irreversibility of the interaction and its two-stage nature. Thus whereas non-covalent binding is not easily conceived to be irreversible, entrapping obviously is likely to be. Proteolytic activity, which is essential for the first stage of interaction, is not required for the maintenance of bind- ing. This was shown in our work by the finding that the complex of radioactive trypsin with $\alpha_{2} \mathrm{M}$ did not dissociate when the bound enzyme was inactivated with Tos- $\mathrm{LysCH}_{2} \mathrm{Cl}$. This would be difficult to explain in terms of single-stage binding, whereas entrapment would not be expected to be reversed by inactivation of the enzyme. The fundamentally non-specific nature of entrapment per se seems to require a first stage of interaction to confer specificity, in this case the proteolytic attack on $\alpha_{2} M$. The nature of the specificity step in the reaction of enzymes with $\alpha_{2} M$ confers on the macroglobulin broad specificity for a group of proteins of similar function. This may be contrasted with the narrower specificity of other proteinase inhibitors such as $\alpha_{1}$-antitrypsin and soyabean trypsin inhibitor, or antibodies. These proteins show a specificity more dependent on structure than on function, and often react with inactive as well as active proteinases.

\section{Some consequences of the unique reactivity of $\alpha_{2} M$}

The specific reactivity of $\alpha_{2} M$ with proteinases makes it a potentially useful research tool. It has already been used in the removal of human kallikrein, a particularly troublesome contaminant, from preparations of thromboplastin antecedent (Harpel, 1971), and might be used in the purification of endopeptidases by methods similar to those of Abe \& Nagai (1972a). It may be useful in deciding whether an enzyme active against the low-molecular-weight substrates of endopeptidases is truly proteolytic.

Physiologically, the most important function of circulating $\alpha_{2} \mathrm{M}$ is probably the trapping of endopeptidases rather than their inhibition. The reason for this is the extreme rapidity with which $\alpha_{2} M-$ enzyme complexes are cleared from the plasma (Niléhn \& Ganrot, 1967; Ohlsson, 1971b,c). In this way, the protein may help in the regulation of extracellular proteolytic activity resulting from clotting and fibrinolysis as well as the release of proteinases from granulocytes and other cells in inflammation. There are also indications that $\alpha_{2} \mathrm{M}$ may contribute to the body's defences against invasive pathogens, since it seems to be the only plasma inhibitor of the keratinase of Trichophyton mentagrophytes (causal agent of ringworm), the neutral proteinase of Fusiformis nodosus (causing ovine foot-root) and the collagenase of Clostridium histolyticum (a gangrene organism). The results of Dolovich \& Wicher (1971) indicate that $\alpha_{2} M$ may also bind the proteinase of Bacillus subtilis taken in by inhalation. Results obtained with papain in rabbits (Thomas, 1964) may be seen as an illustration of this physiological process; it was found that the intravenous injection of the inactive disulphide of papain led to the degradation of ear cartilage, as a result of selective reactivation of the enzyme in this tissue, but when active papain 
was injected it was bound by an $\alpha$-globulin in the plasma and had no effect on cartilage.

In inflammation, the macroglobulin escapes into the tissues and in this situation its inhibitory capacity may become important, for example against the collagenase of rheumatoid synovial fluid (Abe \& Nagai, 1972b).

We conclude that $\alpha_{2} M$ has the unique capacity to bind essentially all active endopeptidases by a twostage mechanism. In the first stage the enzyme probably cleaves a peptide bond in a specific region of the macroglobulin and this leads to the second stage, a conformational change in the $\alpha_{2} M$ whereby the enzyme is entrapped.

Note added in proof (received 20 March 1973) Recent experiments (E. A. Munn \& A. J. Barrett, unpublished work) have confirmed the value of 725000 recently obtained for the molecular weight of human $\alpha_{2} \mathrm{M}$ by Jones et al. (1972). Clearly, substitution of this figure for the previously accepted value of 820000 would decrease the calculated binding ratios of enzymes to $\alpha_{2} M$. For example, the value of 1.04 molecules of trypsin bound per molecule of $\alpha_{2} M$ determined by active-site titration would become 0.92. This does not affect our conclusion that binding is in equimolar ratio.

We thank Mrs. M. A. Brown for her expert technical assistance, and the Arthritis and Rheumatism Council for financial support.

\section{References}

Abe, S. \& Nagai, Y. (1972a) Biochim. Biophys. Acta 278, 125-132

Abe, S. \& Nagai, Y. (1972b) J. Biochem. (Tokyo) 71, 919-922

Adham, N. F., Chakmakjian, Z. H., Mehl, J. W. \& Bethune, J. E. (1969) Arch. Biochem. Biophys. 132, 175-183

Ako, H., Ryan, C. A. \& Foster, R. J. (1972) Biochem. Biophys. Res. Commun. 46, 1639-1645

Arnon, R. (1967) in Antibodies to Biologically Active Molecules (Cinader, B., ed.), pp. 153-179, Pergamon Press, Oxford

Axén, R., Myrin, P.-Å. \& Jansson, J.-C.(1970) Biopolymers 9, 401-413

Barrett, A. J. (1970) Biochem. J. 117, 601-607

Barrett, A. J. (1972a) Anal. Biochem. 47, 280-293

Barrett, A. J. (1972b) in Lysosomes: a Laboratory Handbook (Dingle, J. T., ed.), pp. 46-135, North-Holland Publishing Co., Amsterdam and London

Barrett, A. J. (1973) Biochem. J. 131, 809-822

Barrett, A. J. \& Dingle, J. T. (1972) Biochem. J. 127, 439-441

Baumstark, J. S. (1970) Biochim. Biophys. Acta 207, 318-330

Bender, M. L., Begué-Cantón, M. L., Blakeley, R. L., Brubacher, L. J., Feder, J., Gunter, C. R., Kézdy, F. J., Killheffer, J. V. Jr., Marshall, T. H., Miller, C. G., Roeske, R. W. \& Stoops, J. K. (1966) J. Amer. Chem. Soc. 88, 5890-5913
Berne, B. H., Dray, S. \& Knight, K. L. (1971) Proc. Soc. Exp. Biol. Med. 138, 531-535

Berson, S. A. \& Yalow, R. S. (1966) J. Biol. Chem. 241, 5745-5749

Berthillier, G., Got, R. \& Bertagnolio, G. (1968) Biochim. Biophys. Acta 170, 140-151

Birk, Y. \& Gertler, A. (1971) Proc. Int. Res. Conf. Proteinase Inhibitors 1st (Fritz, H. \& Tschesche, H., eds.), pp. 142-148, Walter de Gruyter, Berlin and New York

Bourrillon, R. \& Razafimahaleo, E. (1972) in Glycoproteins: Their Composition, Structure and Function (Gottschalk, A., ed.), 2nd edn., part A, pp. 699-715, Elsevier Publishing Co., Amsterdam

Boyde, T. R. C. (1969) Biochem. J. 111, 59-61

Boyde, T. R. C. \& Pryme, I. F. (1968) Clin. Chim. Acta 21, 9-14

Brown, S. I., Hook, C. W. \& Tragakis, M. P. (1972) Invest. Ophthalmol. 11, 149-152

Charney, J. \& Tomarelli, R. M. (1947) J. Biol. Chem. 171, 501-505

Chase, T. \& Shaw, E. (1967) Biochem. Biophys. Res. Commun. 29, 508-514

Clamp, J. R. \& Johnson, I. (1972) in Glycoproteins: Their Composition, Structure and Function (Gottschalk, A., ed.), 2nd edn., part A, pp. 612-652, Elsevier Publishing Co., Amsterdam

Dayhoff, M. O. \& Eck, R. V. (1968) Atlas of Protein Sequence and Structure 1967-68, pp. 199-207, National Biomedical Research Foundation, Silver Spring

Dean, R. T. (1973) Biochem. Soc. Trans. 1, 384

Deutsch, D. G. \& Mertz, E. T. (1970) Science 170, 1095-1096

Dolovich, J. \& Wicher, V. (1971) J. Lab. Clin. Med. 77, 951-957

Dunn, J. T. \& Spiro, R. G. (1967) J. Biol. Chem. 242, 5549-5555

Evanson, J. M. (1971) in Tissue Proteinases (Barrett, A. J. \& Dingle, J. T., eds.), pp. 327-345, North-Holland Publishing Co., Amsterdam and London

Feeney, R. E. (1971) Proc. Int. Res. Conf. Proteinase Inhibitors 1st (Fritz, H. \& Tschesche, H., eds.), pp. 162-168, Walter de Gruyter, Berlin and New York

Frénoy, J.-P., Razafimahaleo, E. \& Bourrillon, R. (1972) Biochim. Biophys. Acta 257, 111-121

Fritz, H. \& Tschesche, H. (eds.) (1971) Proc. Int. Res. Conf. Proteinase Inhibitors 1st, Walter de Gruyter, Berlin and New York

Ganrot, P. O. (1966) Acta Chem. Scand. 20, 2299-2300

Ganrot, P. O. (1967) Ark. Kemi 26, 583-591

Ganrot, P. O. \& Niléhn, J.-E. (1967) Clin. Chim. Acta 17, 511-513

Gentou, C., Yon, J. \& Filitti-Wurmser, S. (1968) Bull. Soc. Chim. Biol. 50, 2003-2022

Greenbaum, L. M. (1971) Enzymes, 3rd edn., 3, 475483

Hall, T. C. \& Cocking, E. C. (1965) Biochem. J. 96, 626633

Harpel, P. C. (1970) J. Exp. Med. 132, 329-352

Harpel, P. C. (1971) J. Clin. Invest. 50, 2084-2090

Hartley, B. S. (1960) Annu. Rev. Biochem. 29, 45-72

Haverback, B. J., Dyce, B., Bundy, H. F., Wirtschafter, S. K. \& Edmondson, H. A. (1962) J. Clin. Invest. 41, 972-980 
Heimburger, N., Haupt, H. \& Schwick, H. G. (1971) Proc. Int. Res. Conf. Proteinase Inhibitors 1st (Fritz, $\mathbf{H}$. \& Tschesche, H., eds.), pp. 1-22, Walter de Gruyter, Berlin and New York

Iwamoto, M. \& Abiko, Y. (1970) Biochim. Biophys. Acta 214, 402-410

Jacquot-Armand, Y. \& Krebs, G. (1969) Biochem. Biophys. Res. Commun. 36, 815-822

Jones, J. M., Creeth, J. M. \& Kekwick, R. A. (1972) Biochem. J. 127, 187-197

Katchalski, E., Silman, I. \& Goldman, R. (1971) Advan. Enzymol. 34, 445-536

Keehan, M. F., Smith, M. J., Howard, S. M., Mehl, J. W. \& Beigelman, P. M. (1967) Clin. Chim. Acta 16, 215-220

Koj, A., Chudzik, J., Pajdak, W. \& Dubin, A. (1972) Biochim. Biophys. Acta 268, 199-206

Kueppers, F. \& Bearn, A. G. (1966) Proc. Soc. Exp. Biol. Med. 121, 1207-1209

Lanchantin, G. F., Plesset, M. L., Friedmann, J. A. \& Hart, D. W. (1966) Proc. Soc. Exp. Biol. Med. 121, 444-449

Landureau, J. C. \& Steinbuch, M. (1970) Z. Naturforsch. 25B, 231-232

Lebreton de Vonne, T., Mouray, H., Berthillier, G. \& Got, R. (1971) Comp. Biochem. Physiol. 40B, 439-453

Lebreton de Vonne, T., Mouray, H., Berthillier, G. \& Got, R. (1972) Biochim. Biophys. Acta 257, 365-371

Magnusson, S. (1971) Enzymes, 3rd edn., 3, 277-321

Marchalonis, J. J. (1969) Biochem. J. 113, 299-305

Mehl, J. W., Connell, W. O. \& Degroot, J. (1964) Science 145, 821-822

Merritt, G. C., Egerton, J. R. \& Loi, J. S. (1971) J. Comp. Pathol. 81, 353-358

Mitchel, R., Chaiken, I. M. \& Smith, E. L. (1970) J. Biol. Chem. 245, 3485-3492

Morelis, P., Ambrosioni, J.-C., Got, R. \& Fontanges, R. (1969) C. R. Acad. Sci. D 269, 1453-1454

Nagasawa, S., Hoon, B. H., Sugihara, H. \& Suzuki, T. (1970) J. Biochem. (Tokyo) 67, 821-832

Neurath, H. (1955) Methods Enzymol. 2, 77-83

Niléhn, J.-E. \& Ganrot, P. O. (1967) Scand. J. Clin. Lab. Invest. 20, 113-121

Norman, P. S. (1958) J. Exp. Med. 108, 53-68

Ogston, D., Bennett, B., Herbert, R. J. \& Douglas, A. S. (1973) Clin. Sci. 44, 73-79

Ohlsson, K. (1971a) Scand. J. Clin. Lab. Invest. 28, 225-229

Ohlsson, K. (1971b) Acta Physiol. Scand. 81, 269-272

Ohlsson, K. (1971c) Scand.J. Clin. Lab. Invest. 28, 219-223
Ouchterlony, O. (1967) in Handbook of Experimental Immunology (Weir, D. M., ed.), pp. 655-706, Blackwell Scientific Publications, Oxford and Edinburgh

Rodbard, D. \& Chrambach, A. (1971) Anal. Biochem. 40, 95-134

Sakamoto, S., Goldhaber, P. \& Glimcher, M. J. (1972) Proc. Soc. Exp. Biol. Med. 139, 1038-1041

Sarma, V. R., Silverton, E. W., Davies, D. R. \& Terry, W. D. (1971) J. Biol. Chem. 246, 3753-3759

Saunders, R., Dyce, B. J., Vannier, W. E. \& Haverback, B. J. (1971) J. Clin. Invest. 50, 2376-2383

Schultze, H. E., Heimburger, N., Heide, K., Haupt, H., Störiko, K. \& Schwick, H. G. (1963) Proc. Congr. Europ. Soc. Haemat. 9th, p. 1315, Karger, Basel and New York

Shaw, E., Mares-Guia, M. \& Cohen, W. (1965) Biochemistry 4, 2219-2224

Sobers, H. (1970) Handbook of Biochemistry, 2nd edn., pp. C71-C89, Chemical Rubber Company, Cleveland

Starkey, P. M. (1973) Biochem. Soc. Trans. 1, 381-382

Starkey, P. M. \& Barrett, A. J. (1973) Biochem. J. 131, 823-831

Steinbuch, M. (1971) Rev. Fr. Transfus. 14, 61-82

Steinbuch, M., Pejaudier, L., Quentin, M. \& Martin, V. (1968) Biochim. Biophys. Acta 154, 228-231

Stevens, F. C. (1971) Proc. Int. Res. Conf. Proteinase Inhibitors 1st (Fritz, H. \& Tschesche, H., eds.), pp. 149155, Walter de Gruyter, Berlin and New York

Sugihara, H., Nagasawa, S. \& Suzuki, T. (1971)J. Biochem. (Tokyo) 70, 649-658

Sundaram, P. V., Pye, E. K., Chang, T. M. S., Edwards, V. H., Humphrey, A. E., Kaplan, N. O., Katchalski, E., Levin, Y., Lilly, M. D., Manecke, G., Mosbach, K., Patchornik, A., Porath, J., Weetall, H. H. \& Wingard, L. B. (1971) in Enzyme Engineering (Wingard, L. B., ed.), pp. 15-18, Interscience Publishers, New York

Thomas, L. (1964) Biophys. J. 4, Suppl. 1, 207-213

Wachsmuth, E. D., Fritz, I. \& Pfleiderer, G. (1966) Biochemistry 5, 169-174

Warton, C. W., Crook, E. M. \& Brocklehurst, K. (1968) Eur. J. Biochem. 6, 572-578

Werb, Z. (1973) Biochem. Soc. Trans. 1, 382-383

Wicher, V. \& Dolovich, J. (1971) Int. Arch. Allergy Appl. Immunol. 40, 779-788

Wilson, W. D. \& Foster, J. F. (1971) Biochemistry 10, 1772-1780

Yu, R. F., Grappel, F. \& Blank, F. (1972) Experientia 28, 886 